\title{
Total kalça artroplastisi, rehabilitasyon
}

\author{
Total hip arthroplasty, rehabilitation
}

\author{
Filiz Can
}

Hacettepe Üniversitesi, Sağlık Bilimleri Fakültesi, Fizyoterapi ve Rehabilitasyon Bölümü, Ankara

Total kalça artroplastilerinden sonra hastaların çoğunda, ağrı ile birlikte olmayan bazı fonksiyonel yetersizlikler ve bozukluklar görülür. Kas zayıflıkları ve kas atrofileri kalıcı olabilir. Fonksiyonel aktivitelerde asimetrik ekstremite yüklenmesi ve Trandelenburg yürüyüşüne yol açan kalça abduktor kas zayıflığı, en sık görülen sorundur. Fonksiyon bozuklukları, hareketlilik ve fiziksel aktivite düzeyinde azalmaya ve günlük yaşamda bağımlılığa neden olabilir. Bu nedenle, ameliyattan sonra hastaların rehabilitasyonu önemlidir. Total kalça artroplastilerinde rehabilitasyon, cerrahi öncesi değerlendirme, eğitim ve rehabilitasyonla başlamalıdır. Total kalça artroplastisi sonrası erken kas kuvveti ve fonksiyon kaybını azaltmak için, erken ve yoğun bir rehabilitasyon programı uygulanmalıdır. Cerrahi girişim sonrasındaki rehabilitasyon programı, komplikasyonların önlenmesi, kas re-edükasyonu, kuvvetlendirme ve fleksibilite egzersizleri, yürüme ve denge eğitimi, fonksiyonel egzersizler ve ev egzersizlerinden oluşur. Komplikasyonları önlemek için, ameliyattan hemen sonra hastalara dislokasyon pozisyonları öğretilmeli ve transferler sırasında bunun için önlemler alınmalıdır. Erken dönemdeki rehabilitasyon, aktif ayak bileği pompası, yürüme eğitimi, düşük şiddetli izometrikler ile kalça abduktorları, ekstansörleri ve diz ekstansörleri için izotonik egzersizleri içerir. Eğer çimentolu total kalça artroplastisi uygulanmış ise çift koltuk değneği ile tam ağılık vermeye izin verilir. Çimentosuz total kalça artroplastisi için ise, altı hafta süre ile korumalı veya parsiyel ağırlıkla yürüme uygun görülür; 12. haftaya kadar da ilerletilir. Erken iyileşmeyi uyarmak için akuatik terapi, zayıf kasları kuvvetlendirmek için alçak frekanslı elektrik stimülasyonu ve yük dağılımını değiştirmek için biofeedback kullanımı ek yararlar sağlar. Geç dönemdeki egzersiz programı, fonksiyonel işler, günlük yaşam aktiviteleri, denge, kuvvet, endürans ve kardiyovasküler uygunluğa odaklanan, sekiz egzersiz grubundan oluşur. Kardiyovasküler uygunluğu sağlamak için hastalar, kalçalarına yüklenme yapmayan sporlar ve egzersizlere yönlendirilir.

Anahtar sözcülkler: kalça; artroplasti; rehabilitasyon; fizik tedavi teknikleri
The patients after total hip arthroplasty mostly show some impairments and functional limitations in the absence of pain. Muscle weakness and atrophy around hip joint can persist. Hip abductor weakness is the most common problem which results with Trandelenburg gait and asymmetric limb loading in functional activities. Dysfunction can lead to reduced mobility, physical activity levels and independence in daily life. Thus, rehabilitation of the patient after surgery is important. Rehabilitation for total hip arthroplasty must begin with a preoperative assessment, education and rehabilitation. Earlier initiated and intensive postoperative rehabilitation program must be used to reduce the early loss of muscle strength and function after total hip arthroplasty. Rehabilitation program after surgery comprises of prevention of complications, muscle re-education, flexibility and strengthening exercises, gait and balance training, functional exercises and home exercises. Dislocation position must be taught immediately after surgery and precautions must be emphasized during transfers. Physical therapy program in early term includes ankle pumps, gait training, low-intensity isometrics and isotonic exercises of the hip abductors, extensors and knee extensors. Early full weight bearing with crutches is allowed for cemented THA. Protected weight bearing for six weeks is appropriate for uncemented THA and this is progressed to 12 weeks. Aquatic therapy to facilitate early progression, low-frequency electric muscle stimulation for strengthening of the weak muscles, biofeedback for altering load distribution give additional beneficial effects. Exercise program in late term consisted of eight exercises focused on functional tasks, daily living tasks, balance, strength, endurance and cardiovascular fitness. Sports and physical activities which avoid impact loading of the hip should be encouraged to maintain cardiovascular fitness.

Key words: hip; arthroplasty; rehabilitation; physical therapy techniques

- Illetişim adresi: Prof. Dr. Filiz Can, Hacettepe Üniversitesi, Să̆lık Bilimleri Fakültesi; Fizyoterapi ve Rehabilitasyon Bölümü, Ankara Tel: 0312 - $3051576 / 172$ e-posta: filizcan2002@yahoo.com

- Geliș tarihi: 28 Eylül 2013 Kabul tarihi: 24 Ekim 2013 


\section{T} otal kalça artroplastileri (TKA), temel olarak eklem stabilitesini, hareketliliğini, yaşam kalitesini artırmak, yürümeyi geliştirmek için yapılan bir cerrahi işlemdir. ${ }^{[1-5]}$

TKA ameliyatından 3-6 ay sonra yapılan çalışmaların sonuçları, ağrı azalması ve eklem hareketliliği yönünden hastanın, ortopedistin ve fizyoterapistin gayet memnun olduğunu göstermektedir. ${ }^{[1,5]}$ Ancak TKA sonrası hastalarda, yapılan ameliyatın başarısına, uygun protez seçimine, protezdeki gevşeme veya ekstremite dizilimindeki bozukluk gibi ortopedi ile ilgili olarak ortaya çıkabilecek sorunlara bakmaksızın, çeşitli düzeyde fonksiyonel kayıplar ortaya çıkar. Bu konuda yapılan çalışmalara göre, kalça replasman cerrahisinden sonra genellikle hastaların günlük yaşam aktivitelerinde zorluk ve çok seviyeli kas zayıflıkları, ${ }^{[6-9]}$ kalça abduktor kaslarında zayıflık, ${ }^{[6,7,10]}$ kalça ekstansör ve fleksör kaslarında zayıflık ${ }^{[6,11]}$ ve kalça adduktorlarının maksimal kas kuvvetinde uzun süreli azalma (6-48 ay) gibi ortadan şiddetliye doğru giden fonksiyon bozuklukları veya yetersizlikler ${ }^{[6,12,13]}$ ortaya çıkar. Hem ameliyat öncesi, hem de ameliyat sonrasında, yürümede bozukluklar veya fonksiyonel kayıplar ve asimetriler görülür. ${ }^{[9,14-19]}$

Genel olarak TKA'lı hastalarda cerrahi öncesi dönem dahil olmak üzere cerrahi sonrası dönemde de görülebilecek kas-iskelet sistemi sorunları ve fonksiyon kayıpları şu şekilde özetlenebilir:

- Kas zayıflıkları (başta kalça abduktorları, ekstansörleri, fleksörleri, adduktorları, gluteus minimus, tensor fascia lata kaslarında zayıflıklıklar). ${ }^{[6-11,20]}$

- Eklem hareket genişliğinde azalma ve fleksibilite kaybı (başta kalça eklemi olmak üzere diz ve ayak bileği eklemleri). ${ }^{[9,21]}$

- Kas sertlikleri ve kontraktürler (iliopsoas, rectus femoris, tensor fascia lata, gastrosoleus ve lumbal ekstansörlerde kısalık veya kontraktür). ${ }^{[12,20,22]}$

- Ekstremite dizilim bozuklukları (aynı taraf dizde, aynı taraf ayakta, karşı taraf dizde bozukluklar), ${ }^{[12,20]}$

- Denge sorunları ve ameliyatlı bacak üzerine ağırlık aktarmada sorun. ${ }^{[23,24]}$

- Yürümede asimetri ve Trandelenburg yürüyüşü, yürüme hızında azalma, yürüme parametrelerinde anormallikler. ${ }^{[9,14-17,19,21]}$

- Günlük yaşam aktivitelerinde kayıp veya yetersizlik. [12,25-27]

Bütün bu fonksiyon bozuklukları ve yetersizlikler, hastalarda ameliyattan yıllar sonra bile sürebilen hareket kayıplarına yol açar. Ameliyat yapılmış alt ekstremitedeki kas zayıflıkları, yürümedeki zorluklar ve hareket kayıpları, hastalarda düşme riskini artırır. Düşme riski, düzgün olmayan zeminlerde, basamaklarda veya merdivenlerde daha da artar; yüksek morbidite ve mortalite oranı ile kırık veya diğer kas-iskelet sistemi sorunlarına yol açar. ${ }^{[12,16,17,20,24,28]}$ Disfonksiyon veya fonksiyon kayıpları, hareketlilik ile birlikte, fiziksel aktivite düzeyini ve bağımsız yaşama kapasitesini de düşürür. Hasta, günlük yaşam aktiviteleri ve diğer aktivitelerde yardım gerektirir veya tam bağımlı olur. Dönüşümlü olarak kas zayıflıkları ve kas sertlikleri artar; eklemlerde esneklik kaybı olur ve eklem hareket genişliği azalır. Bu durum, hastalardaki aktivite kaybını ve bağımlılığı daha da arttırır.

TKA sonrası hastaların optimal iyileşmesi için, fonsiyonlardaki kayıpların giderilmesi veya kaybolan fonksiyonların geri kazanılması gerekmektedir. Bu nedenle kalça artroplastileri sonrasında fizyoterapirehabilitasyonun yeri ve fizyoterapistin tedavideki rolü oldukça önemlidir. ${ }^{[1,2,4,8,12,22,29,30-32]}$

TKA'nın fizyoterapi ve rehabilitasyon programı genelde şunları içerir:

1. Cerrahi öncesi rehabilitasyon ve bilgilendirme,

2. Cerrahi sonrası rehabilitasyon ve komplikasyonları önleme,

3. Yürüme eğitimi ve fonksiyonel rehabilitasyon,

4. Ev egzersizleri ve tavsiyeler

TKA sonrası fizyoterapi ve rehabilitasyonun, hastaların ağrısını azaltmada, eklem hareketliliğini arttırmada, fonksiyonel düzeyini geliştirmede olduğu kadar, cerrahi sonrası komplikasyonları önlemede veya azaltmada da çok yararlı etkileri vardır. ${ }^{[12,32,33]}$ Ayrıca sağlık ile ilgili yaşam kalitesini arttırmada ve hastanede kalış süresini azaltmada çok etkilidir. ${ }^{[2,32,34,35]}$ TKA sonrası düşmeler, kas zayıflıkları ve zayıflıklara bağlı protezde gevşeme sorunları gibi durumlar için rehabilitasyonun geç dönemdeki koruyucu etkisi de önemlidir. ${ }^{[2,24]}$

Literatürde, cerrahi öncesi egzersizler ve bilgilendirme ile ilgili farklı sonuçlar bulunmuş olsa da, ${ }^{[36-39]}$ cerrahi sonrası eğitim ve rehabilitasyonun, hastaların klinik gelişimindeki önemi bütün çalışmalarda çok etkin bulunmuş ve sistematik derleme sonuçları ile de desteklenmiştir. ${ }^{[33,34,40]}$

Yaşam kalitesi ile ilgili olarak yapılan bir sistematik derlemede TKA ile ilgili 20 çalışma incelenmiş ve TKA sonrası uygulanan rehabilitasyonun, hastalar için faydalı etkiler ortaya çıkardığı ve sağlıkla ilgili yaşam kalitesini çok belirgin olarak arttırdığı bulunmuştur. Bu yararlı etkilerin en çok cerrahi sonrası ilk 3-6 ay içinde gözlendiği bildirilmiştir. ${ }^{[3]}$ 
Kalça artroplastilerinde rehabilitasyonun başarısı üç etkene bağlıdır:

- Cerrahi öncesi rehabilitasyon (travmaya bağlı TKA hastalarında cerrahi öncesi rehabilitasyonun dönemi yoktur)

- Cerrahi işlem

- Cerrahi sonrası rehabilitasyon ${ }^{[29]}$

\section{TKP'li hastaların cerrahi öncesi dönemdeki değerlendirmesi}

Kalçada osteoartrit veya dejeneratif nedenlerle TKA ameliyatı olmak için bekleyen hastalarda cerrahi öncesi değerlendirme, hem cerrahi öncesi dönemde verilecek egzersiz programını planlamak, hem de cerrahi sonrası dönemdeki hedefleri belirlemek için kullanılır. Ayrıca, cerrahi öncesi bir değerlendirme ile belirlenecek olan fiziksel fonksiyonel düzey, cerrahi sonrası dönemde ulaşılacak başarı veya fiziksel düzey için önemli bir göstergedir. ${ }^{[25,36,41]}$ Bu nedenle hastalar, cerrahi öncesi rehabilitasyon programı öncesinde fizyoterapistler tarafından ağrı şiddeti, postür, eklem hareket genişliği, esneklik, kas kuvveti, atrofi ve ödem, ekstremite uzunluğu, yürüme, fonksiyonel düzey ve günlük yaşam aktiviteleri yönünden detaylı bir şekilde değerlendirilir. ${ }^{[1,8,29,42]}$ Cerrahi öncesi ve cerrahi sonrası farkların, sadece kalça için değil, diz kinematikleri için de geçerli olması nedeniyle, bu hastaların değerlendirmesinde ayak bileği dahil tüm alt ekstremitenin gözden geçirilmesi önemlidir. ${ }^{[9]}$

TKA'lı hastaların cerrahi öncesi fiziksel fonksiyonel düzeylerini belirlemek için çeşitli testler ve ölçekler kullanılır. Literatürde fonksiyonel değerlendirme için en çok kullanılan objektif ve subjektif test ve ölçekler, eklem hareket genişliği ve eklem fleksibilite testleri, denge testleri, merdiven çıkma testi, yürüme analizi, 6 Dakikalık Yürüyüş Testi, Zamanlı Kalk ve Yürü Testi (Timed-Up and Go Test), Haris Kalça Skoru, Kas Fonksiyon İndeksi, Kalça Disfonksiyon ve Osteoartrit Başarı Skorudur. ${ }^{[12,38,41,43]}$

Son yıllarda, fizyoterapistlerin bazı hastalıklar için geliştirdikleri ICF (International Classification of Functioning) modeli ile değerlendirme, 2012 yılından itibaren TKP'li hastalar için de uygulanmaya başlamıştır. ICF değerlendirme modeli daha çok fonksiyonlara dayalı, hastaların gereksinimlerini etkileyebilecek kişisel ve çevresel faktörlerin dikkate alınarak, fonksiyonel kayıpların şiddetine göre sınıflandırmanın yapıldığı bir modeldir. 2012 yılında TKA'lı hastalar için, ICF modelinin hazırlandığı ilk çalışmada kısa bir dökümantasyon yayınlanmış ve bu dökümantasyonda TKA'lı hastalar iki ayrı klinik kategori ve birbirini izleyen üç bakım sınıflaması ile ICF modeline göre değerlendirilmiştir. ${ }^{[44]}$

\section{CERRAHI ÖNCESI REHABILITASYON}

Hastanın cerrahi sonrası rehabilitasyondaki tecrübesini ve başarısını arttırmak için cerrahi öncesi rehabilitasyonda çeşitli fizyoterapi-rehabilitasyon yaklaşımları kullanılabilir.

Cerrahi öncesi rehabilitasyon döneminde verilecekler şunları kapsamalıdır:

- Cerrahi öncesi rehabilitasyon programını planlamak ve cerrahi sonrası rehabilitasyonun başarı düzeyi hakkında ön fikir edinebilmek için kapsamlı bir fizyoterapi-rehabilitasyon değerlendirmesi yapmak,

- Ameliyat ve ameliyat sonrası görülebilecek kısıtlamalar, olası komplikasyonlar ve bunların önlenmesi ile ilgili bilgilendirme yapmak,

- Ameliyat sonrası kalça çıkığını önlemek için dikkat edilmesi gereken pozisyonlar ve aktiviteler ile uyulması gereken diğer kurallar hakkında bilgi vermek,

- Cerrahi öncesi dönemdeki rehabilitasyon ile ilgili genel bilgilendirme yapmak ve cerrahi öncesi rehabilitasyonun yararları konusunda hastayı bilgilendirmek,

- Cerrahi sonrası rehabilitasyonun içeriği ve hedefleri ile ilgili bilgi vermek, rehabilitasyondaki gerçekçi hedefleri saptamak,

- Ameliyat sonrası kullanılacak araç-gereçler (tuvalet yükselticisi, çorap ve ayakkabı çekeceği vb.) ve yürüme yardımcıları (walker, koltuk değneği, baston) konusunda bilgi vermek ve yürüme yardımcıları için uygun ölçüyü almak,

- Hastaya yürüme ve yürüme ile ilgili fonksiyonlar (yürüme yardımcıları ile yürüme, merdiven inipçıkma, yokuş inip-çıkma, oturup-kalkma vb.) ve diğer günlük yaşam aktiviteleri ile ilgili (arabaya inip-binme, banyoya girme, kalça ve dizden bükülmeden yerden bir şey almaya çalışma vb.) pratikler yaptırmak,

- Ameliyat sonrası ev ve çevre düzenlemesi ile ilgili bilgi vermek, hasta için emniyetli bir ortam oluşturulmasını sağlamak,

- Hastayı ve ailesini olası düşmelere karşı bilgilendirmek ve düşmelerin önlenmesi için hastayı eğitmek,

- Uygulanan cerrahi işlemi korunması ve protezin uzun süre kullanabilmesi için yapılması gerekenler, kaçınılması gerekenler ve tavsiye edilen sporlar ve etkinlikler konusunda bilgi vermek, 
- Cerrahi öncesi egzersiz programını planlamak, uygulamak ve hastanın egzersize karşı motivasyonunu arttırarak, cerrahi sonrası rehabilitasyona hazırlamak. ${ }^{[25,29,39]}$

Bu bilgiler, hastalar ve hasta yakınlarına, sözel (özel görüşme, sınıf konferansları vb.), yazılı (kitapçık, broşür, kitap vb.) veya görsel (video, tanıtım filmleri vb.) araçlarla verilebilir. ${ }^{[39]}$ Yapılan bir çalışmada, TKA'।ı hastalarda cerrahi öncesi eğitim sınıfı ve kitapçık ile bilgilendirmenin, hastanede kalış süresini kısalttı̆̆ı, buna bağı ılarak hastane masraflarını azalttığı, hastalarda ameliyat ile ilgili daha gerçekçi beklentilere ve daha yüksek tatmine yol açtığı bulunmuştur. ${ }^{[37]}$ Sonuç olarak, cerrahi öncesi rehabilitasyon programı almış ve ameliyata iyi hazırlanmış hastalarda:

- Erken ambulasyon sağlanır ve erken ambulasyonun tüm katkılarından yararlanilır. ${ }^{[25,33,38,39]}$

- Hastanede kalış süresi azalır. [25,36,37,39]

- Cerrahi sonrası ağrı kesicilere olan gereksinim azalır. ${ }^{[33,39]}$

- Daha gerçekçi beklentiler olur ve hasta tatmini artar. ${ }^{[37]}$

Cerrahi öncesi dönemde verilecek egzersizler genel olarak şunları kapsar:

- Üst ekstremite kaslarına kuvvetlendirme egzersizleri (koltuk değneği kullanımı ve vücuda destek olmak için gerekli kasları kuvvetlendirme).

- Karın ve sırt kaslarına kuvvetlendirme egzersizleri.

- Kalça fleksörlerine germe egzersizleri (bu hastaların çoğunda bu kaslarda görülen kontraktür nedeniyle).

- Kalça eklemi başta olmak üzere ilgili alt ekstremitedeki eklemlerde maksimum ağrısız hareket sınııının sağlanması.

- Kuadriseps ve gluteal kaslar için izometrik egzersizler.

- Kalçaya gelecek stresleri azaltmak için için gluteus medius başta olmak üzere kalça çevresi kasları için kuvvetlendirme egzersizleri.

- Diz ekstansörlerine kuvvetlendirme egzersizleri.

- Pulmoner fonksiyonları geliştirmek ve cerrahi sonrası dönemdeki sekresyonların atılmasını sağlamak için solunum egzersizleri.

- Cerrahi sonrası dönemde kullanılacak olan yürüme programının öğretilmesi ve yürüme yardımcıları ile yürüme ve merdiven inip-çıkma eğitimi. ${ }^{[1,29,39]}$
Literatürde TKA ameliyatı olacak hastalarda cerrahi öncesi rehabilitasyon programı olarak uygulanan egzersiz yaklaşımlarının ağrıyı azaltabileceği ve fiziksel fonksiyonları arttırabileceği, kanıta dayalı çalışmalarla gösterilmiştir. ${ }^{[3,40]}$ Oosting ve arkadaşlarının yaptığı bir çalışmada, fizyoterapist tarafından uygulanan ev temelli yoğun bir cerrahi öncesi egzersiz programının, özellikle TKA ameliyatı olacak çok yaşlı hastalarda fonksiyonel sağlıkla ilişkili parametreler yönünden önemli gelişmeler sağladığı ortaya çıkarılmıştır. Cerrahi öncesi rehabilitasyon programı sırasında, ameliyat öncesi yürüme yardımcılarının tanıtılması ve yürüme ile ilgili tüm tekniklerin önceden öğretilmesi nedeniyle, çok yaşlı hastalarda bile erken ambulasyonla ilgili fonksiyonların rahatlıkla başarılabildiği gösterilmiştir. ${ }^{[38]}$

\section{TKA'da cerrahi sonrası rehabilitasyonun amacı}

TKA'da cerrahi sonrası rehabilitasyonunun ilk ama$\mathrm{Cl}$, özellikle cerrahi sonrası erken dönemde oluşabilecek komplikasyonları önlemek veya en aza indirgemektir. İkinci amaç ise, TKA ameliyatının hastaya verdiği potansiyonel olanağı, fizyoterapi ve rehabilitasyon yöntemleriyle maksimum fonksiyona dönüştürmektir. TKA ameliyatlarından sonra hastayı emniyetli bir şekilde günlük yaşam aktivitelerine, eski fonksiyonel düzeyine, işine ve sosyal yaşamına geri döndürmek ve hastanın yaşam kalitesini arttırmak, cerrahi sonrası rehabilitasyonun son hedefi olmalıdır.

Cerrahi sonrası rehabilitasyonun amaçları şunlardır:

- Kalça çıkığı, derin ven trombozu, dekübitis ülseri, akciğer komplikasyonları, kalça fleksiyon kontraktürü gibi komplikasyonları önlemek veya minimale indirmek.

- Hasta için en uygun egzersiz programını planlamak ve uygulamak.

- Patalojik yürüme biçimini düzeltmek ve normal yürüyüşü sağlamak.

- Fonksiyonları veya fonksiyonel düzeyi artırmak.

- Hareketliliği artırmak ve GYA'da bağımsızlığı sağlamak.

- Yaşam kalitesini artırmak.

- Emniyetli bir şekilde işe ve sosyal yaşama geri dönüşü sağlamak.

- Verilecek düzenli fiziksel aktivite veya egzersizler ve gerekli tavsiyeler ile protezin uzun süreli kullanımını sağlamak veya ömrünü uzatmak. ${ }^{[29]}$

Bu amaçlar doğrultusunda hazırlanan cerrahi sonrası rehabilitasyon programı çoğu kez başarı ile sonuçlanır ve hasta memnuniyeti en üst düzeyde olur. Ancak, 
cerrahi sonrası rehabilitasyonun hedefleri ve rehabilitasyon programlarının içeriği ne kadar iyi düzenlenmiş olursa olsun, hastalar arasında rehabilitasyon sonuçları yönünden bazı farkıılıklar ortaya çıkabilir, çünkü bu sonuçları etkileyen bazı olumsuz etmenler vardır.

\section{Rehabilitasyon sonuçlarını olumsuz yönde etkileyen etmenler}

- İleri yaş (özellikle 80 yaş ve üstü olmak). ${ }^{[41,45]}$

- Kadın hasta. ${ }^{[41,45]}$

- Cerrahi öncesi dönemdeki aşırı ağrı. ${ }^{[41]}$

- Cerrahi öncesi dönemde kalça çevresi kaslarında zayıflık ve atrofiler, esneklik kaybı. ${ }^{[7,10,41]}$

- Zayıf diz ekstansör kasları. ${ }^{[46]}$

- Cerrahi öncesi düşük fiziksel aktivite düzeyi veya zayıf fonksiyonel düzey ve yürüme skoru. [25,39,41]

- Denge ve koordinasyon sorunu.

- Çoklu eklem tutulumu.

- Çoklu hastalık veya fonksiyon bozukluğu.

- Rehabilitasyonla ilgili düşük beklenti ve egzersize karşı düşük motivasyon.

Uygulanan cerrahi işleme ek olarak bu etmenler de rehabilitasyonun sonuçlarını değiştirebilir veya etkiyebilir. Bu nedenle TKA'lı hastalarda rehabilitasyon programı, standart bir program olmak yerine, genel ilkeler dışında bireysel özellik taşımalıdır. Bu etmenler ve önceki dönemde yapılan değerlendirme sonuçları göz önünde bulundurularak hazırlanacak bir rehabilitasyon programı, hastaya özel olarak hazırlanmış ideal bir program olur ve tedavinin başarı oranını arttırır.

\section{Erken cerrahi sonrası rehabilitasyonun etkileri}

TKA'ı hastalarda ameliyat sonrası erken dönemde hastanede uygulanan fizyoterapi ve rehabilitasyon programı, cerrahi komplikasyonları veya komplikasyon risklerini azaltır ve ameliyat sonrası hastanede kalış süresini kısaltır. ${ }^{[30,34,35,47,48]}$ Rehabilitasyonun, hastanede kalış süresi üzerine olan etkisini inceleyen 11 yıllık bir tarama çalışmasında, TKA'lı hastaların hastanede kalış süresi 1990 yılında ortalama 9,7 gün olarak bulunurken, 2000 yılında hızlandırılmış rehabilitasyon programları ile 5,3 güne düştüğü görülmüştür. Genelde kadın hastaların hastanede kalış sürelerinin ve hastane masraflarının erkeklere göre daha fazla olduğu bulunmuştur; ancak, bu farkın da 2000 yılında azaldığı ortaya çıkmıştır. ${ }^{[35]}$

Yapılan bir çalışmada TKA'lı hastalarda hem subjektif, hem de objektif değerlendirme yöntemleri ile ölçülen fiziksel fonksiyonlardaki artışın, ilk üç ay içinde en yüksek olduğu bildirilmiştir. Fiziksel fonksiyonel durumdaki bu artışın, 3-12 ay arasında yavaşladığı ve özellikle subjektif değerler için en alt düzeye indiği gösterilmiştir. İlk üç ayda Haris Kalça Skoru, Kalça Disfonksiyon Skoru gibi subjektif değerlendirme sonuçlarının çok büyük bir gelişme gösterdiği ve hasta memnuniyetinin en yüksek düzeye ulaştığı bulunmuştur. Objektif yöntemlere göre yapılan değerlendirmede ise en büyük gelişmenin, yürüme mesafesi ve merdiven aktivitelerinde olduğu görülmüştür. ${ }^{[41]}$

Cerrahi sonrası erken ve hedefe yönelik olarak uygulanan rehabilitasyonun, fonksiyonlar ve yaşam kalitesi yönünden yararlı etkiler sağladığı gösterilmiştir; bu yararlı etkiler için rehabilitasyonun ayaktan veya evde verilebileceği öne sürülmüştür. ${ }^{[2,32]}$

Bu çalışmaların da gösterdiği gibi, fiziksel fonksiyonlardaki gelişmenin ilk üç ay içinde en yüksek düzeyde olduğu görüşünden yola çıkılarak TKA'lı hastalarda ameliyattan hemen sonra erken rehabilitasyonun başlatılması ve ilk üç aylık dönemde fonksiyonların maksimuma çıkarılması gerekmektedir. Hasta, ameliyat sonrası serviste uygulanan fizyoterapiden bazı yararlı etkiler sağlayarak taburcu olabilir; ancak, bu sürede özellikle kas kuvveti ve fonksiyonlar tam olarak iyileşemediği için, kasları kuvvetlendirmek, kas sertliklerini gidermek ve fiziksel fonksiyonları arttırmak için fizyoterapi-rehabilitasyon programına taburcu olduktan sonra da devam edilmesi gerekir. ${ }^{[2]}$

\section{CERRAHI SONRASI REHABILITASYON}

Ideal olarak fizyoterapi programı, önceden yapılan değerlendirmeler ışığında hastanın yaşına, eşlik eden diğer hastalıklara, uygulanan cerrahiye (çimentolu, çimentosuz ve hibrid tip artroplasti) veya cerrahi tekniğe ve hastanın cerrahi öncesi yürüme ve fiziksel fonksiyon düzeyine bağı ılarak düzenlenmeli; rehabilitasyon sırasında bütüncül bir yaklaşım sergilenmelidir. Rehabilitasyon programı, hastanın gereksinimlerine yanıt verebilecek şekilde ve güvenli bir program olmalı ve bireysel özellik taşımalıdır. Genel programa ek olarak önceki sorunları ve biyomekanik yetersizlikleri de çözebilecek fizyoterapi-rehabilitasyon yaklaşımları uygulanmalıdır.

Cerrahi sonrası dönemde kullanılan fizyoterapirehabilitasyon programı genel olarak şunları içerir:

- Cerrahi sonrası rehabilitasyon programının amaçları, kısa ve uzun dönem hedefleri, genel içeriği ve süresi ile ilgili bilgilendirme.

- Cerrahi sonrası erken dönemde (ilk altı hafta) kalçaya gelen stresleri azaltmak ve kalça ekleminin olası çıkı̆̆ını önlemek için pozisyonlama ve eğitim. 
- Sekresyonları çıkarmak ve pulmoner fonksiyonları geliştirmek için göğüs fizyoterapisi (solunum egzersizleri, solunum kontrolü, etkili öksürme teknikleri).

- Derin ven trombozu gelişimini veya tromboembolik olayları önlemek için yapılan uygulamalar (elastik çorap veya bandaj kullanımı, bacakların yükseltilmesi, klasik masaj, aktif ayak bileği hareketleri).

- Ağrıyı azaltmak, dolaşımı arttırmak ve kasların kasılma yeteneğini arttırmak için elektroterapi yöntemlerinin kullanımı (Transkuteneal Elektriksel Sinir Stimülasyonu = TENS, Enterferansiyel veya Diadinamik akım uygulamaları, Elektrik stimülasyonu, Biofeedback vb.).

- Aktif, aktif yardımlı veya dirençli egzersizler (alt ve üst ekstremiteler ve gövde kaslarını kuvvetlendirmek için).

- Uygun yürüme teknikleri kullanılarak asimetrik yürümenin azaltılması, normal veya normale yakın yürümeyi sağlayacak yürüyüş eğitimi.

- Fonksiyonel egzersizler ve fonksiyonel eğitim.

- Fiziksel uygunluğu arttırmak için verilecek uygun sporlar veya fiziksel aktiviteler. ${ }^{[29]}$

Hastalara, erken cerrahi sonrası dönem boyunca (6-8 hafta) yatarken bacaklarını abduksiyonda tutmaları veya abduksiyon yastığı kullanmaları, ameliyatlı taraf üzerine yan yatmamaları, sağlam taraf üzerine yan yatışlarda veya yatakta dönmeler sırasında bacaklar arasına kalın bir yastık koymaları önerilir. Kalçalarını aşııı stres ve yüklenmelerden korumaları; orta hattı geçen adduksiyondan, fleksiyonda iç rotasyon başta olmak üzere kalçanın rotasyonlarından, nötrali geçen kalça ekstansiyonundan, yan yatış pozisyonundaki abduksiyon hareketinden ve oturmada veya ayakta $90^{\circ}$ 'yi geçen kalça fleksiyonundan kaçınmaları öğütlenir. Hastalara, bacak bacak üstüne atmamaları ve özellikle yatağa girme ve çıkma sırasında sağlam bacaklarını ameliyatlı bacağın altından geçirerek taşımamaları öğütlenir. Bu dönem sırasında, hastaların alçak yerlere oturmaları, gövdeden öne doğru eğilmeleri, çömelmeleri ve alaturka tuvalet kullanmaları yasaklanır. Bu nedenle, alçak sandalye veya koltuklara ek minder koymaları, tuvalet yükselticisi kullanmaları, öne doğru eğilerek yapılması gereken işler veya ayakkabı-çorap giyme gibi aktiviteler sırasında uzun saplı bazı aparatlardan veya ayakkabı-çorap çekeceklerinden yararlanmaları tavsiye edilir. Ayrıca ayakta iken ameliyatı bacak üzerinden veya ameliyatlı bacağa tam ağırlık vererek dönmek yerine, küçük adımlarla direkt olarak gövdeden dönülmesi gerektiği yolunda tavsiyelerde bulunulur (Şekil 1-5). [4,42,43,49] Yatakta uzun süre yatması gereken yaşlı hastalarda bası yaralarının açılmaması için iki saatte bir pozisyon değiştirilmesi gerekir.

Cerrahi sonrası erken dönemde derin ven trombozu gelişimini veya tromboembolik olayları önlemek için, ilaç proflaksisine yardımcı olacak bazı fizyoterapi uygulamalarına da yer verilmesi gerekir. Bunun için, kompresyon bandajları veya elastik çorap kullanımından, klasik masaj uygulamasından, bacakların kalp seviyesinin üstüne çıkacak şekilde yükseltilmesinden, aktif ayak bileği pompası olarak tanımlanan ayak bileği egzersizleri başta olmak üzere aktif alt ekstremite egzersizlerinden ve derin solunum egzersizlerinden yararlanilır. ${ }^{[29,43,49]}$

TKA'lı hastaların hastanede yatış süresi boyunca uygulanan cerrahi sonrası rehabilitasyon programları, yukarıda belirtilen birçok etmene göre bazı küçük farklılıklar gösterse de, özellikle erken dönemde benzer özellikler gösterir. Hastanede yatan bir hasta için geleneksel fizyoterapi programı, solunum egzersizleri, ayak bileği hareketleri, düşük şiddetli izometrikler, kalça abduktorları ve ekstansörleri ile diz ekstansörlerine izotonik egzersizler ve yürüme eğitimini içerir. Altı haftalık bu programdan sonra rehabilitasyon programı, daha ağırlıklı olarak kas kuvvetlendirme ve fleksibilite egzersizlerine yoğunlaşır. Özellikle, kalça abduktorları, ekstansörleri, diz ekstansörleri ve ayak bileği çevresi kaslarına kuvvetlendirme, kalça fleksörleri, lumbal ekstansörler ve Hamstring'lere germe egzersizleri uygulanır. ${ }^{[12,42,43]}$

Fizyoterapi programında özellikle yaşlı hastalar için denge, koordinasyon ve propriosepsiyonu geliştirecek egzersizlere yer verilir ve yaşılıların düşmeye karşı artmış olan eğilimleri göz önünde bulundurularak yürüme eğitimi sırasında en yüksek güvenlik sağlanır. Düşme ile düşmelerin önlenmesi ile ilgili olarak hem hastaya, hem de ailesine ve bakım verenlere eğitim verilir. Egzersizler sırasında, özellikle yaşlı hastaların kardiyopulmoner fonksiyonları ve fiziksel uygunluk düzeyleri dikkate alınır; fiziksel yeteneklerini aşırı zorlayacak ve egzersize olan katımlarını olumsuz yönde etkileyecek zor egzersizlerden kaçınılır.

TKA'ı hastaların rehabilitasyonuna, hastaneden taburcu olduktan sonraki dönemlerde de devam edilir. Genellikle bu programlarda kas kurvetini, kas gücünü, yürüme hızını ve hareketliliği arttırmak için kuvvetlendirme egzersizleri ve merdiven inip-çıkma gibi fonksiyonel aktiviteler kullanılır. Yapılan çalışmalarla evde veya rehabilitasyon merkezlerinde geç dönem uygulanan rehabilitasyon programlarının, TKA'ı yaşlı hastalarda 
görülen kronik ağrıları ve bacaktaki kas sertliklerini azalttığı, fiziksel fonksiyonları arttırdığı ve düşmeleri azalttığı ortaya konulmuştur. ${ }^{[2,31,50]}$ Bu yararlı etkileri ortaya çıkarabilmek için, ev programı olarak verilecek egzersizler başta olmak üzere tüm egzersizlerin, genel fizyolojik ilkelere dayalı, basit ve iyi düzenlenmiş egzersizler olmasına ve temel fonksiyonel aktiviteleri kapsamasına özellikle dikkat edilmelidir.

\section{Elektrik stimülasyonu}

TKA'lı veya kalça cerrahisi geçirmiş yaşlı hastalarda rehabilitasyon programı içine nöromusküler elektrik stimülasyonunun ilave edilmesinin, kas fonksiyonlarını arttırmada etkili olduğu ve rehabilitasyonun yararını arttırdığı bildirilmiştir. ${ }^{[20,47]}$ Gremeaux ve arkadaşlarının TKA'lı hastalar üzerinde yaptığı bir çalışmada, bir gruba konvansiyonel fizyoterapi, diğer gruba da konvansiyonel fizyoterapiye ek olarak kuadrisepse ve baldır kaslarına, beş hafta süre ile haftada beş gün alçak frekanslı akım uygulaması yapılmıştır. Çalışmanın sonucunda elektrik stimülasyonu uygulanan hastaların ameliyat edilen bacaklarındaki kuadriseps kas kuvveti, ameliyat olmayan bacaklarının kuadriseps kurveti ile benzer duruma gelmiş ve kuadriseps kasındaki bu gelişme elektrik stimülasyonu uygulanmayan diğer gruba göre daha büyük olmuştur. Hastaların fonksiyonel düzeylerinde de daha büyük bir artış olmuş ve bağımsızlık düzeyleri artmıştır. ${ }^{[51]}$ Sonuç olarak, alçak frekanslı akım uygulamaları, özellikle kas zayıflıkları daha belirgin olan yaşı ıastalarda erken kas kuvvetlendirme üzerine oldukça yararlı oldukları için, TKA'lı hastaların cerrahi sonrası erken dönem rehabilitasyon programları içinde etkin bir şekilde kullanılabilirler. ${ }^{[12,20,47]}$

\section{Hidroterapi ve akuaterapi}

Hidroterapinin ve akuaterapinin hem ISı etkisi ile genel gevşeme sağlaması, hem de suyun kaldırma özelliği ile hareketlerde kolaylık sağlaması nedeniyle TKA'lı hastalar için oldukça yararlı etkileri vardır. ${ }^{[52-56]}$ Akuaterapi, özellikle kas fonksiyonlarında tam kayıp olan hastalarda çok etkilidir. Suyun kaldırma gücü, hastanın eklemleri ve yumuşak dokuları üzerine gelen stresleri azaltır; suyun ılıklığı ise kan akışını hızlandırır ve kaslara gelen oksijeni arttırır; bu da iyileşmeye yardımcı olur ve ağrının duyusal olarak yorumlanmasını düzenler. ${ }^{[8]}$ Suyun içinde gövdenin ve ekstremitelerin stabilizasyonu için kasların çalışma ve yüklenmesine gerek kalmadan, hareket açığa çıkar. Suyun kaldırma kurvetinin etkisiyle eklem ve dokular üzerine gelen yükler azalır; ameliyat yapılan ekstremiteye erken dönemde yük vermek kolaylaşır ve erken yük verme sonucu, özellikle gluteus medius kasına gelen stresler ve makaslama güçleri azalır. ${ }^{[5,56]}$ Su içinde bulunma ile ortaya çıkan hidrostatik güçler egzersiz ile birleştiğinde, alt ekstremite ödemi azalır. Akuaterapi uygulaması sırasında yapılan su içi egzersizleri zayıf kasları kuvvetlendirir, eklem hareketlerini restore eder, ağrıyı azaltır ve fonksiyonları arttırır. Ayrıca genel gevşeme sağlar, egzersize olan motivasyonu arttırır. ${ }^{[52]}$ Suyun kaldırma kuvvetine ters yönde yapılan uygulamalarla dirençli egzersiz yapabilme özelliği, egzersizler ve yürüme eğitimi için oldukça yararlı ve güvenli bir ortam oluşturur. Bu olumlu etmenlerin bir araya gelmesi sonucu hidroterapi ve akuaterapi, yürüme, basamak çıkma, çömelme (squat) gibi hareketlerle fonksiyonel kuvvetlendirmeye yardımcı olur; yürüme yardımcıları olmadan normal simetrik yürüme biçimi ile yürüme eğitimine erken başlamayı sağlar. ${ }^{[55,56]}$

Yapılan bir çalışmada TKA'ı hastalarda rehabilitasyon programına ek olarak cerrahi sonrası dördüncü günden itibaren 14 gün süre ile uygulanan su içi egzersizlerinin, erken kas kuvvetlendirmede ve özellikle abduktor kas kuvvetlendirmede oldukça etkili olduğu ve erken cerrahi sonrası dönemde güvenle kullanılabildiği gösterilmiştir. ${ }^{[56]}$

TKA'lı hastalarda üç haftalık hidroterapi programının uygulandığı bir başka çalışmada, yürüme hızı, adım uzunluğu, yürüyüşün durma ve sallanma fazlarının birbirlerine oranları gibi yürüyüşün parametrelerinde ve dengede anlamlı gelişmeler olduğu bulunmuştur. ${ }^{[53]}$ TKA sonrası hastaların yaşı ileri bile olsa, hidroterapi ile tam iyileşmenin sağlanabildiği gösterilmiştir; ancak, bunun için hastaların hastaneden taburcu olduktan sonra da fizyoterapist gözetiminde ev egzersizlerini sürdürmelerinin gerekliliği üzerinde durulmuştur. ${ }^{[52,54]}$

Sonuç olarak, ortopedik cerrahiden sonraki ilk günlerdeki erken iyileşme için çok önemli olması nedeniyle, erken cerrahi sonrası dönemde rehabilitasyon programına ek olarak verilen hidroterapi veya akuatik fizyoterapi programı, hastaların iyileşmesine önemli katkılar sağlar.

\section{Egzersiz}

TKA'lı hastalarda ameliyattan aylar sonra devam eden ve ameliyat yapılan ekstremite kaslarında belirgin kas zayıflıkları ve atrofiler ile seyreden durumları sıklıkla görmek olasıdır. Ameliyattan bir yıl sonra yapılan çalışmalar, hastalarda ağrı olmaksızın, bozuklukların ve fonksiyonel kısıtlamaların sürdüğü yolundadır. ${ }^{[7,57]}$ $\mathrm{Bu}$ hastalarda görülen bozukluklar, ameliyat yapılmış kalça tarafında azalmış kas kuvveti ${ }^{[57]}$ ve azalmış postural stabilitedir. ${ }^{[58]}$ Fonksiyonel kısıtlamalar ise, azalmış yürüme hızı ${ }^{[26]}$ ve merdiven aktiviteleridir. ${ }^{[27]}$ Sonuç olarak, TKA'lı hastalar fonksiyonlarını ölçmek 
için kullanılan birçok değerlendirme ölçümlerinden, cerrahi sonrası geç dönemde bile düşük puanlar alırlar. ${ }^{[57]}$ Bu nedenle, TKA'ı hastalarda fonksiyonların ve bozuklukların giderilmesinde egzersizlerin önemi ön plana çıkar.

TKA'lı hastalarda kalça kaslarının kuwvetinin, yürüme hızı ve fonksiyonlar için önemli bir belirleyici olduğu gösterilmiştir. ${ }^{[10]}$ Kalça çevresindeki kasların kontraksiyonu ile oluşturulan güç bileşenleri veya güç taşıyıcıları, kalça eklem reaksiyon güçlerinin birincil belirleyicileridir. Çift bacak üzerinde duruşu sağlamak için kalça eklem reaksiyon güçleri vücut ağırlığının bir katı kadar iken, tek bacak üzerinde duruş sırasında 2-3 vücut ağırlığı kadardır. Yürüme sırasında kalça eklem reaksiyon güçleri, yürümenin hızına bağlı olarak 2-4 kat vücut ağırlığı kadar olur. Merdiven inip-çıkma, femurun proksimalindeki (veya baş-boyun kısmındaki) belirgin torsiyonel güçlere ek olarak kalça eklemi üzerine 3-4 kat yük bindirir. Köprü kurma hareketi için pelvisi basit olarak yukarı kaldırma hareketi, kalça çevresi kaslarının kontraksiyonunu gerektirdiği için, vücut ağırlığının 5-6 katı kadar kalça eklem reaksiyon gücü oluşturur. ${ }^{[59]}$

TKA'lı hastalarda en büyük sorun olan abduktor kas zayıflı̆̆, yürümenin duruş fazı sırasında ameliyatlı tarafta artmış adduksiyon ve gövdenin ipsilaterale doğru eğilmesi ve bu faz boyunca azalmış kalça abduktor momenti ile sonuçlanır. ${ }^{[8]}$ Ayrıca bu kasların zayıflığının, eklem instabilitesi, protezde gevşeme ve diğer komplikasyonlarla ilişkili olarak büyük bir risk etmeni olduğu bilinir. ${ }^{[60]}$ TKA'lı hastalarda topallama olmaksızın iyi bir yürüyüş biçimi sağlamak ${ }^{[61]}$ ve düşmeleri önlemek için ${ }^{[13]}$ alt ekstremite kaslarının, özellikle kalça abduktor kaslarının, yeterince kuvvetli olması gerekir. Bu nedenle egzersizlerde gluteus medius kası başta olmak üzere, tüm kalça çevresi kaslarının en yüksek düzeyde kuvvetlendirilmesine özellikle önem verilmesi gerekir. Kalça çevresi kaslarını kuvvetlendirmek, sadece kas kuvvetindeki zayıflığı önlemek için değil, fonksiyonel düzeyi arttırmak ve cerrahi sonrası geç dönem komplikasyonları önlemek için de önemlidir. ${ }^{[50]}$

Sonuç olarak, kalça çevresi kasları zayıf olan TKA'lı hastalar hem cerrahi öncesi, hem de cerrahi sonrası dönemdeki değişik aktiviteler sırasında, yüksek oranda kalça eklem reaksiyon güçlerine maruz kalırlar. Bu nedenle de, bu güçlere karşı koyabilecek kuvvetli kalça çevresi kaslarına gereksinimleri vardır. Bunun için kalça çevresi kasları değişik egzersiz ve aktivitelerle kuvvetlendirilmeli ve kalçaya gelen reaksiyon güçleri azaltılmalıdır. ${ }^{[59]}$ Bunlara ek olarak fonksiyonları geliştirmek, denge ve koordinasyon ile ilgili reaktif cevapları, günlük yaşam aktiviteleri ile ilgili yetenekleri ve kardiyovasküler uygunluğu arttırmak için de değişik egzersizlere yer verilmelidir.
TKA'ı hastalarda egzersiz programları temel olarak sekiz egzersiz grubundan oluşur:

1. Solunum egzersizleri.

2. Kalçanın esnekliği için normal eklem hareketleri (ROM egzersizleri) ve germe egzersizleri.

3. Kuvvetlendirme egzersizleri.

4. Yürüme egzersizleri.

5. Denge ve propriosepsiyon egzersizleri.

6. Günlük yaşam aktivitelerine ve fonksiyonlara yönelik egzersizler.

7. Endurans egzersizleri.

8. Fiziksel uygunluk veya kardiyovasküler uygunluk egzersizleri.

Kas kuvvetini arttırmak için kullanılacak olan egzersiz eğitiminin şiddetinin, bir maksimum tekrarın \%60'। kadar olması gerekir. ${ }^{[48]}$ Gluteus medius kuvvetlendirmeye, önce aktif eklem hareketi olarak sırtüstü yatış pozisyonunda başlanır; daha sonra yan yatış pozisyonunda devam edilir. Bir süre sonra da, yan yatış pozisyonunda dirençli egzersizlere geçilir. Dirençli egzersizlere, başlangıçta hafif ağırlıklarla ve kuvvet kolu kısa tutularak başlanır; daha sonra daha büyük ağırlıklar ve uzun kuwvet kolu ile devam edilir. ${ }^{[12]}$ Gluteus medius kuvvetlendirme eğitimi, ayakta yapılan egzersizlerle ilerletilir. Kasın stabilizatör etkisini restore etmek için alternatif olarak kalçalara ağırlık aktarma eğitimi verilir. Kasın dinamik etkisini restore etmek için ise ayakta kalça abduksiyon hareketleri yaptırılır. Kası ileri düzey kuvvetlendirmek için, kum torbaları veye terrabantlardan da yararlanılır. Aynı şekilde kalça ekstansörleri, fleksörleri ve adduktorları dahil olmak üzere tüm kalça çevresi kasları en yüksek düzeyde kuvvetlendirilir. ${ }^{[29]}$

Yapılan çalışmalarda, TKA'ı hastalarda kuadriseps kas zayıflığının yürüme ve diğer fonksiyonlarda yetersizliğe yol açtığı gösterildiği için, rehabilitasyonda kuadriseps kasını kuwvetlendirmeye de özellikle yer verilmelidir. Ancak kuadriseps kuwetlendirme egzersizi, düz bacak kaldırma egzersizi şeklinde değil, normal kuadriseps izometrik egzersizi veya izotonik diz ekstansiyonu şeklinde verilmelidir. Düz bacak kaldırma egzersizi, kalça eklemi üzerine hareket düzlemi dışında çok geniş yüklenme yaptığı ve eklemde oldukça büyük güçlere yol açtığı için özellikle erken dönemde (ilk altı hafta) kesinlikle kaçınılması gereken bir egzersizdir. ${ }^{[22,49]}$ Kuadriseps ve kalça kasları için ilgili kalçaya yük vererek uygulanan kuvvetlendirme egzersizleri ve postural stabilite egzersizleri ile hastaların kas kuwetleri, postural stabiliteleri ve algılanan fonksiyonel düzeylerinde anlamlı gelişmeler sağlanabilir. ${ }^{[8,22]}$ 
Kuvvetlendirme egzersizlerinin dışında, özellikle bu hastaların hemen hemen tamamında kısalmış olan kalça fleksörleri başta olmak üzere, $M$. Gastrosoleus ve $M$. Hamstring'lere verilecek nazik germe egzersizleri, pelvis ve kalça mekaniğinin restorasyonu için çok önemlidir; ancak bu egzersizler sırasında kalça ekleminde çıkığa veya aşırı yüklenmeye yol açacak pozisyonlardan kaçınılmalıdır. ${ }^{[12,22]}$

TKA'lı hastaların egzersiz programı içinde denge ve koordinasyon egzersizleri de önemlidir. ${ }^{[12,42]}$ Bunun için oturmada her iki kalça üzerine eşit ağılık verme, ayakta denge, ağırlık aktarma, tek bacak üzerinde denge gibi egzersizlerden yararlanılır. Ayrıca koordinasyon için destekli ve desteksiz olarak oturmadan ayağa kalkma, ayakta sağa, sola veya arkaya dönme gibi egzersizler kullanılır. Hem denge reaksiyonlarını stimüle etmek, hem de baldır kaslarını kuvvetlendirmek için ayakta bilateral topuk kaldırma, alternatif topuk ve ayak ucu kaldırma egzersizlerine ağırlık verilir ve bu egzersizler sırasında tüm hareketlerin birbirleriyle koordine bir şekilde çalışmasına dikkat edilir.

Jan ve arkadaşlarının TKA'lı hastalar üzerinde yaptığı bir çalışmada, her iki kalçaya normal eklem hareketleri, kalça fleksörleri, ekstansörleri ve abduktorları için kuvvetlendirme egzersizleri ve 30 dakikalık yürüme eğitiminden oluşan 12 haftalık bir ev programı ile, kas kuvveti, yürüme hızı ve fonksiyonel skorda anlamlı gelişmeler elde edilmiştir. Bu araştırmacılar, fizyoterapist tarafından iyi düzenlenmiş bir ev programının, TKA'lı hastalarda kas kuvveti, yürüme hızı ve fonksiyonlardaki gelişme için oldukça etkili olduğunu, ancak hastaların bu programa düzenli katılımlarının zor olması nedeniyle, ev programının fizyoterapist gözetiminde uygulanmasının daha yararlı olduğu sonucuna varmışlardır. ${ }^{[50]}$

\section{TKA'lı hastalarda yürüme biçimi}

TKA'lı hastalarda yürüme, bu hastalarda görülebilecek fonksiyonel eksikliği veya yetersizliği ölçmede kullanılan standart ve pratik bir değerlendirme yöntemidir. TKA ameliyatı sonrası hastaların ağrılarında belirgin azalma olmasına rağmen, yürüme, merdiven inipçıkma gibi motor yeteneklerde çoğunlukla normal düzeye ulaşılamaz. ${ }^{[15,17]}$ TKA'yı takiben, hastaların çoğunda asimetrik bacak yüklemesi veya asimetrik yürüme görülür. Ameliyat ile gluteus medius kasındaki zayıflığın yanı sıra, kalça eklem propriosepsiyonunda veya eklem pozisyon hissinde de bir miktar değişiklik olur ve bu durum bacaklar arasında bir asimetriye veya asimetrik yüklemeye yol açar. ${ }^{[16,62]}$ Yürüme sırasındaki ağırlık taşıma asimetrisini ölçmek için, gövde merkezinden laterale olan sapma[63], ameliyatlı bacaktaki vertikal yer reaksiyon güçlerindeki fark ${ }^{[64]}$ veya açısal gövde hareketi gibi parametreler kullanılır. Bacaklar arasındaki bu asimetrik yükleme veya koordinasyonun, ameliyat olmamış kalça eklemi üzerine de aşırı yükleme yapma riski vardır. Sağlam veya ameliyat olmamış bacağın aşırı yüklenmesi, bu kalçada da osteoartrit gelişimine ve özellikle yaşlılarda düşmelere yol açabilir. ${ }^{[24]}$

Yapılan bir metaanaliz sonucuna göre, TKA'lı hastalarda yürüme hızı azalmıştır; adım uzunlukları ve sagittal düzlemdeki kalça eklem hareket genişliklerinde de bir azalma vardır. ${ }^{[21]}$ TKA'lı hastaların yürüme hızı, ameliyattan sonraki 2-4 yıl süre boyunca normal değerlerin altında kalır. ${ }^{[6]}$ Yürüme hızındaki azalma, genellikle yürümenin erken duruş fazı sırasındaki ekstansör moment gücünde azalma, yürüme sırasındaki kalça ekstansiyon hareket sınırında azalma, anterior pelvik rotasyon, diz fleksiyon ve ayak dorsifleksiyonunda artış ile birliktedir. ${ }^{[64]}$ Bu hastalar için klinik önemi büyük olan kalça abduktor momenti de azalmıştır. ${ }^{[21]}$ Ayrıca ameliyatlı taraftaki ayak bileği eklemi ve ameliyat edilmemiş karşı taraf kalçanın yürüme kinematikleri de etkilenmiş̧ir. ${ }^{[19]}$ Hastaların çoğu artmış pelvik rotasyon, pelvik obliklik ve pelvik tilt ile yürürler. ${ }^{[12]}$

Kalça ekleminin patolojilerinde veya dejeneratif durumlarda antaljik yürüyüş (ağrıdan kaçınma yürüyüşü) biçimi gelişir ve bu durum zaman içinde alışkanlığa dönüşür. Kronik ağrı, kalça çevresi kaslarının uzun süreli zayıflı̆̆, kalça eklem propriosepsiyonundaki kayıp ve ameliyat öncesindeki bu alışılmış hareket paterni, ameliyat yapılan tarafta uzun süreli veya kalıcı fonksiyon kaybına veya topallamaya yol açar. Bu antaljik hareket biçimi, bazen çok iyi bir cerrahi tedavi ve/veya rehabilitasyon uygulanmış olsa bile tamamen düzelmez. ${ }^{[19,64]}$

Bennett ve arkadaşlarının 2008 yılında yaptıkları bir çalışmada, genç yaştaki TKA'ı hastaların cerrahi sonrası 10. yılda bile normal yürüme kinematiklerini sağlayamadıkları; ameliyattan yıllar sonra bile kas atrofileri ve kalıcı kas sertliklerinin, hastaların yürüyüş kinematiklerini etkilediği sonucuna varılmıştır. ${ }^{[28]}$

Yapılan diğer bir çalışmada, TKA ameliyatı sırasında uygulanan cerrahi yaklaşımın yürüme biçimi üzerine olan etkisini incelemek üzere, anterolateral yaklaşım ile lateral yaklaşım yapılan hastalara yürüme analizi yapılmış ve yürüme parametreleri karşılaştırılmıştır. Anterolateral yaklaşım yapılan hastaların tümünde sağ ıklı kişilere benzer bir yürüme biçimi olduğu ortaya konulmuş; fonksiyonel ve normale yakın bir yürüyüş için, cerrahi sırasında direkt lateral yaklaşım yerine, anterolateral yaklaşımın tercih edilmesi gerektiği vurgulanmıştır. ${ }^{[66]}$ Aynı şekilde, yüzeyel artroplastilerden sonra hastaların normal yürüme biçimine dönüşünün, TKA'lı hastalara göre daha iyi ve hızlı olduğu; bunun da kalça abduktor kas kuvveti ile ilişkili olduğu sonucuna varılmıştır. ${ }^{[18]}$ 
TKA'lı hastalarda anormal yürüyüş biçimini veya disfonksiyonu gidermek ve yürümedeki topallamayı azaltarak normal yürüme biçimini sağlamak, rehabilitasyonun ana hedeflerinden birisi olmalıdır. Bu nedenle cerrahi sonrası rehabilitasyon programında, yürüme eğitimi ve yürümeye normalliğini kazandıracak uygulamalara yer verilmesi çok önemlidir. ${ }^{[19,31,67]}$

\section{Yürüme eğitimi ve fonksiyonel rehabilitasyon}

Yürüme fonksiyonu, yürümenin günlük yaşam için çok yüksek öneme sahip olması nedeniyle tüm fonksiyonel düzey ile yakından ilişkilidir. Bu nedenle yürüme fonksiyonu, fonksiyonel iyileşmenin önemli bir belirleyicisidir. ${ }^{[68]}$ Rehabilitasyonda bunun için kullanılabilecek biofeedback, kas kuvvetlendirme, denge ve yürüme eğitimi ve fonksiyonel eğitim gibi çeşitli yöntemler vardır. ${ }^{[9,41,67]}$

TKA'dan sonra uygulanan rehabilitasyon programı, her hastanın sensorimotor yeteneklerine göre uygulamayı ve adaptasyonu gerektirir. İmplantasyon yapılmış bir eklemi ameliyattan hemen sonra hızlı bir şekilde yüklemek veya kullanmak, özellikle yaşı hastalarda denge kaybına ve hatta düşmelere neden olabilir. Yaşlanmaya bağlı olarak postural kontrol ve denge yeteneği azalır; kalça kasları dahil olmak üzere tüm postural kasları kasabilme yeteneğinde de bir azalma olur. $\mathrm{Bu}$ nedenle özellikle yaşlı hastalar için erken cerrahi sonrası dönemde ameliyatlı bacağa yük vermek oldukça zordur ve asimetrik bacak yüklemesi genç hastalara göre daha fazla olur.

TKA ameliyatı sonrası hastaların ameliyatlı taraf kalçalarına erken yük vermesini engelleyen nedenler şunlardır:

- Erken dönemde hızlı iyileşme göstermeyen ve kasılma yeteneği kaybolmuş veya azalmış kaslar (özellikle yaşılıarda belirgin düzeyde).

- Azalmış eklem pozisyon hissi veya propriosepsiyon.

- Cerrahi öncesi dönemden kalan alışkanlığa bağlı olarak eklem üzerine ağılık verme ile ilgili kaçınma reaksiyonu.

- Aşırı yüklenme ile artan kalıcı ağrı.

En uygun şartlardaki rehabilitasyonda, henüz yetersiz olan ekleme herhangi bir yükleme yapmadan önce, kas kuvvetini, fleksibiliteyi ve propriosepsiyonu geliştirmek, ilk amaç olmalıdır. Bunları geliştirmeden önce yapılacak olan erken yükleme, eklemin yetersizliğini arttırır. ${ }^{[69]}$

Rehabilitasyonun erken döneminde kalça eklemine olan bu zararlı yüklenmeyi azaltmak için çoğunlukla yürüteç (walker), koltuk değneği ve baston gibi yürüme yardımcılarından faydalanılır. Yürüme, çimentolu TKA uygulanmış hastalar için ameliyat sonrası ilk haftalarda koltuk değnekleri veya yürüteç ile bacak üzerine tolere edilebildiği kadar tam veya tama yakın ağırık verilerek, çimentosuz TKA uygulanmış hastalar için ise altı hafta süre ile kısmi ağırlık verilerek veya ayak ucu değdirilerek (toe-touch) yapılır. TKA'lı hastaların yürümesi için yardımcı araçlardan çoğunlukla koltuk değnekleri kullanılsa da, özellikle denge sorunu olan yaşlı hastalarda, olası düşmeleri önlemek için ilk haftalarda yürüteç kullanılması daha emniyetli olur. Bazı yaşlılarda da koltuk değneklerinin kullanımı ile ilgili bir koordinasyon bozukluğu olduğu için koltuk değnekleri ile yürümede zorluk ve korku olur. Bu durumda hastanın yürüyüş korkusunu azaltmak, erken dönemde hareketliliği sağlamak ve fonksiyonları geliştirmek için koltuk değneği yerine, ilk birkaç hafta yürüteç kullanımı tercih edilebilir. Çimentolu kalça protezlerinde üç hafta sonra koltuk değnekleri, 5.-6. haftanın sonunda da baston bırakılır. Çimentosuz kalça protezlerinde altıncı haftaya kadar koltuk değnekleri ile kısmi ağırlık verilerek yürünür. Daha sonra koltuk değnekleri ile tam ağırlık verilerek yürümeye geçilir. 8.-12. haftalar arasında baston ile yürünür ve 12 . haftanın sonunda baston bırakılır. Çoklu sorunu olan, sık düşen veya denge sorunu olan aşırı yaşlı hastalarda bu süreler uzayabilir veya güvenlik amacıyla özellikle ev dışındaki yürüyüşler için baston kullanımına devam edilebilir. ${ }^{[1,22]}$

TKA'lı hastalarda baston veya koltuk değneğinin karşı tarafta kullanımı, sanılanın aksine normal resiprokal yürümeyi kolaylaştırır ve kalçaya gelen temas güçlerini azaltır. Aynı tarafta veya ipsilateral kullanımda ise kalçaya gelen temas güçleri, karşı tarafta veya kontralateral kullanıma göre daha büyük olur. Kontralateral kullanım ile kalçaya gelen temas güçlerinin azalmasının en önemli nedeni, unilateral duruş fazı sırasında pelvisin dengede olmasını sağlayan kalça abduktor kas zorlanmasının azalmasıdır. ${ }^{[70,71]}$ Bu konuda yapılan çalışmaların tümünde, kontralateral baston kullanımının, kalça abduktorları üzerine gelen yüklenmeyi veya bu kasın zorlu kullanımına olan gereksinimi belirgin bir şekilde azalttığı ve bunun sonucunda kas kontraksiyonu ile ilişkili eklem kompresyonunu düşürdüğü bildirilmiştir. Bu nedenle TKA'lı hastaların yürüme eğitimi sırasında baston veya koltuk değneğinin kontralateral veya karşı tarafta kullanılması gerekir. ${ }^{[70-73]}$

Yeterli abduktor kas kuvveti olmayan hastalarda erken ağırlık verme, düzeltilmesi oldukça zor olan Trandelenburg yürüyüşü ile sonuçlanır. Trandelenburg yürüyüşü, zayıf implant fiksasyonu nedeniyle de olabilir. Eğer abduktor kaslar travma veya dejenerasyondan dolayı oldukça zayıf ise, kas kuvveti gelişene kadaryürüme yardımcılarının kullanımına devam edilmelidir. ${ }^{[22,76]}$ 
Aksi takdirde abduktorlarda aşırı yüklenmeye bağlı kas spazmı veya ağrı, bursit gibi yumuşak doku sorunları ve eklemde artmış kompresif güçlere bağlı erken aşınma sorunları ortaya çıkabilir.

Kuvvetlendirme eğitimi sürerken yürüme yardımcıları ile güvenli ve normale yakın bir yürüyüş eğitimi için çalışılmalı, yürüme yardımcıları ile ameliyatlı kalça üzerine giderek artan bir yük verme eğitimi ile hastanın ağırlık taşıma toleransı arttırılmalıdır. TKA'ı hastalarda yürüme eğitimi, hasta bastonu bıraktıktan sonra da sürmeli, gluteus medius kasının zayıflığına veya alışkanlığa bağIı Trandelenbug yürüyüşü veya asimetrik yürüyüş düzeltilmeye çalışılmalıdır. Hastalar ayaktaki egzersizler sırasında bilateral destek yüzeyinden unilateral destek yüzeyine doğru ilerletilmeli ve ameliyatlı tarafa daha fazla yük vermesi için cesaretlendirilmelidir. Çimentolu TKA uygulanmış hastalar için 12 hafta sonra ise tamamen bağımsız ve desteksiz olarak yürüme eğitimine geçilmelidir. ${ }^{[12,39]}$

Hastalarda "öğrenilmiş asimetrik yük dağılımı", sadece kas zayıflı̆̆ına ait bir durum değil, adaptif bir davranış olarak da nitelendirilmelidir. Bu nedenle TKA'lı hastaların rehabilitasyonunda bu durum göz önünde bulundurulmalı, kuvvetlendirme egzersizlerinin yanı sıra, proprioseptif egzersizlere de yer verilmeli, proprioseptif duyu yollarını stimüle edecek değişik fonksiyonel aktivitelerden yararlanılmalıdır. Ayrıca, davranışsal eğitim yöntemleri ile bu öğrenilmiş hareket veya yürüme biçimi değiştirilmeye çalışılmalıdır. ${ }^{[16]}$

Yürüme eğitimi biofeedback ile birlikte yapılırsa, asimetrik yüklenme ve ağırlık taşıyan diğer eklemlerin ikincil dejenerasyonuna yol açabilecek anormal eklem yüklenmesi de azalır. ${ }^{[15,74]}$ Yapılan bir çalışmada, PEDAR ${ }^{\circledR}$ mobil sistemi kullanılarak, TKA'lı hastaların kısmi ağırlık vermeyi öğrenmeleri için biofeedback eğitimi verilmiş ve hastaların biofedback ile kısa sürede kısmi ağırlık vermeyi öğrendikleri görülmüştür. ${ }^{[75]}$ Yapılan randomize kontrollü bir çalışmada, TKA'lı hastalarda yürüyüşü stimüle etmek için, hastalar haftada üç gün 15 dakika süre ile sekiz hafta boyunca koşu bandında, ayak-yer reaksiyon güçlerinin normal zamanlamaya göre görüntülerini izleyerek yürütülmüşlerdir. Çalışmanın sonucunda, koşu bandı ile yürümenin TKA'ı hastalarda daha simetrik yürümeyi sağlamaya yardımcı olduğu ve bunun görüntülü biofeedback ile daha da arttırılabileceği kararına varılmıştır. ${ }^{[14]}$

Hastalarda, oturma konumundan ayağa kalkma sırasındaki asimetrik bacak yüklenmesinin, ayakta durma veya yürümeye göre daha kritik olduğu ve görsel duyunun, ağırlık taşıma yeteneğinin kontrolünde sadece küçük bir rol oynadığı bildirilmiştir. Bu nedenle yürüme ve oturma konumundan ayağa kalkma eğitimi, hastaların fonksiyonel rehabilitasyon programında özellikle yer almalıdır. ${ }^{[16]}$

Rehabilitasyonun ileri dönemlerinde, herhangi bir yürüme desteği olmaksızın yürüyüşs sırasındaki denge ve koordinasyon restore edilmeli ve hastanın normal yürüyüş biçimi ile yürümesi için eğitim verilmelidir. Normal yürüyüşün kinematikleri (çift ve tek destek dönemlerinin süreleri, duruş ve sallanma fazı sırasında olması gereken alt ekstremite eklemlerindeki açısal hareketler vb.) ve yürümeye normalliği kazandıran parametreler (destek yüzeyi, adım uzunluğu, adım genişliği ve kadans vb.) üzerinde yoğunlaşılmalıdır. Fonksiyonları geliştirmek için, değişik hız, destek yüzeyi ve adım uzunluğunda yürüyüşler yapılmalı ve farklı zeminlerde yürüyüşler denenmelidir. Daha sonra otomatik yürümeyi sağlamak ve koruyucu refleks yanıtları oluşturmak için, yürümenin hızı ani arttırılarak veya engel atlayarak yürüme, yan ve geri yürüme, yürüme sırasında konuşma veya herhangi bir şey taşıma gibi çok amaçlı işlere yönelik eğitimler verilmelidir. ${ }^{[2]} \mathrm{Bu}$ konuda yapılan bir çalışmada, TKA sonrası yürüme fonksiyonunundaki iyileşmeyi göstermek için, yürümeye ek olarak verilen bir kognitif iş, üç farklı yürüme hızında yapılmış ve altıncı haftadan sonra farklı hızlardaki yürüme sırasında adım uzunluğunun arttığı gözlenmiştir. Ayrıca yürüme hızı ile adım uzunluğu arasındaki ilişki önemli bulunmuştur. ${ }^{[68]}$

Bu nedenle fonksiyonel eğitim, rehabilitasyon programında odaklanılması gereken çok önemli bir eğitimdir ve diğer ortopedik durumlarda olduğu gibi, TKA ameliyatından sonraki hem erken, hem de geç dönem rehabilitasyonu için gereklidir. Hedefe yönelik ve bireye özel olarak planlanan, hem hastane, hem de ev ortamında uygulanan iyi bir egzersiz programı ile TKA'lı hastaların hem yaşam kalitesinde, hem de fiziksel fonksiyonlarında ve yürümelerinde anlamlı gelişmeler sağlanır.

\section{Önerilen fiziksel aktivite ve sporlar}

Kalçada dejeneratif hastalıklara bağlı olarak eklem replasman cerrahisi gerektiren hastalar, artrit nedeniyle azalmış fiziksel aktivite ile uyumlu olarak düşük fiziksel kondüsyona sahiptir. Bu nedenle, kardiyovasküler fonksiyonları ve fiziksel kondüsyonu en uygun duruma getirmek için düzenli bir egzersiz programı tavsiye edilir. ${ }^{[1,43,49]}$

Bu hastalara, kalçada çıkığa, aşıı eklem reaksiyon güçlerine veya aşırı eklem yüklenmesine yol açacak fiziksel aktivitelerden kaçınmaları öğütlenir. Örneğin, alçak sandalye veya koltuklarda oturma, çömelme pozisyonunda, eller ve dizler üzerinde veya öne doğru eğilerek yapılan ev veya bahçe işleri yapma, çorap 
ve ayakkabı giyme, yere oturma, araba kullanma, ağır kaldırma veya yokuş çıkma gibi aktivitelerin yapılması kalça eklemine çok yük bindireceği için kaçınılması gereken aktivitelerdir. ${ }^{[4,43]}$ Bu nedenle hastaların, ameliyattan sonra ortalama 5-6 hafta süre ile araba kullanmaları ve normal bir sandalyede oturmaları, yedi hafta süre ile ağır çanta taşımaları, sekiz hafta süre ile oturmada veya ayakta $90^{\circ}$ 'yi aşan kalça fleksiyonu yapmaları, 12 hafta süre ile kalça fleksiyonda eller ve dizler üzerinde çalışmaları ve portatif merdivene çıkmaları yasaklanır. ${ }^{[4]}$

Rehabilitasyonun ileri dönemi veya spora dönüş döneminde hastalara, protezin uzun süreli kullanımını tehlikeye sokacak ve kalça eklemine etkisi yüksek yüklemeler yapacak futbol, basketbol, voleybol, hentbol, yüksek atlama, tenis, jogging veya koşma gibi sporlardan kaçınmaları önerilir. Bunların yerine, bu tip yüklenmelere ve yineleyen streslere yol açmayan, yürüme, yüzme, bisiklete binme (oturma yeri yükseltilerek) ve golf gibi az risk içeren sporlar tavsiye edilir. ${ }^{[49]}$

\section{HASTANEDE DÖNEMINDE KULLANILACAK REHABILITASYON PROGRAMI ÖRNEĞi}

\section{(Yazara ait)}

\section{1. gün:}

- Pozisyonlama (protezli tarafi 15-20 ' lik abduksiyon ve nötral pozisyonda konumlanır).

- Adduksiyondan ve özellikle fleksiyonda iç rotasyondan kaçınma.

- Ameliyatı kalça üzerine yatmadan kaçınma.

- Derin ven trombozunu önlemek için elastik çorap ve aktif ayak bileği hareketleri.

- Solunum egzersizleri.

- Sekresyonları çıkarmak için göğüs fizyoterapisi.

- Sağlam alt ekstremite ve her iki üst ekstremitelere kuvvetlendirme.

- Aktif kalça fleksiyonu-ekstansiyonu (ağrı sınırı içinde).

- Kuadriseps, gluteus maksimus ve kalça abduktorları için izometrik egzersizler.

- Yatak içinde destekli oturma.

- Emniyetli bir şekilde yataktan kalkma ve yatağa girme (yatak içi transfer aktiviteleri).

- Yüksek bir sandalyede kısa sürelerle destekli oturma.

- Ayağa kalkma, koltuk değnekleri veya yürüteç ile oda içinde yürüme.
Cerrahi sonrası 2. ve 3. günler:

- Solunum egzersizleri, aktif ayak bileği egzersizleri, pozisyonlamaya ve kaçınılması gereken hareketlere devam.

- Karın-sırt kasları, üst ekstremite ve sağlam alt ekstremiteyi kuvvetlendirme (dirençli).

- Aktif kalça fleksiyon ve ekstansiyonu (90o'den daha büyük kalça fleksiyonunundan kaçınarak).

- Sırtüstü pozisyonda kalça abduksiyonu (eğer trokanterik osteotomi yapıldıysa limitli sınırda).

- Kuadrisepste refleks kas inhibisyonu varsa, kuadriseps için elektrik stimülasyonu.

- Kuadriseps kası için kuvvetlendirme (düz bacak kaldırma egzersizinden kaçınmalı!).

- Sağlam tarafa yan yatma ve dönme (bacaklar arasında kalın bir yastık ile).

- Yatak içinde veya yüksek bir sandalyede kısa sürelerle desteksiz oturma.

- Oturmada diz ekstansiyonu ve alternatif ayak bileği hareketleri.

- Koltuk değnekleri veya yürüteç ile koridorda yürüme.

- Tuvalet ve banyoya transfer aktiviteleri.

Cerrahi sonrası 4. gün:

- Önceki günlerde yapılan egzersizlere devam.

- Ayakta denge ve koordinasyon egzersizleri (destekli).

- Yürüme eğitimi (normal yürüme paterni için eğitim).

- Koltuk değnekleri ile yürüme.

- Koltuk değnekleri ile merdiven inip-çıkma.

\section{Cerrahi sonrası 5.-6. günler:}

- Önceki günlerde yapılan egzersizlere devam.

- Kalçada eklem hareketliliğini ve kas kuvvetini arttıran egzersizler.

- Yürüme mesafesi ve oturma süresi arttırılır.

\section{Taburcu olurken:}

- Ev programı.

- GYA sırasında dikkat edilmesi gereken durumların öğretilmesi.

- Arabaya transfer. 


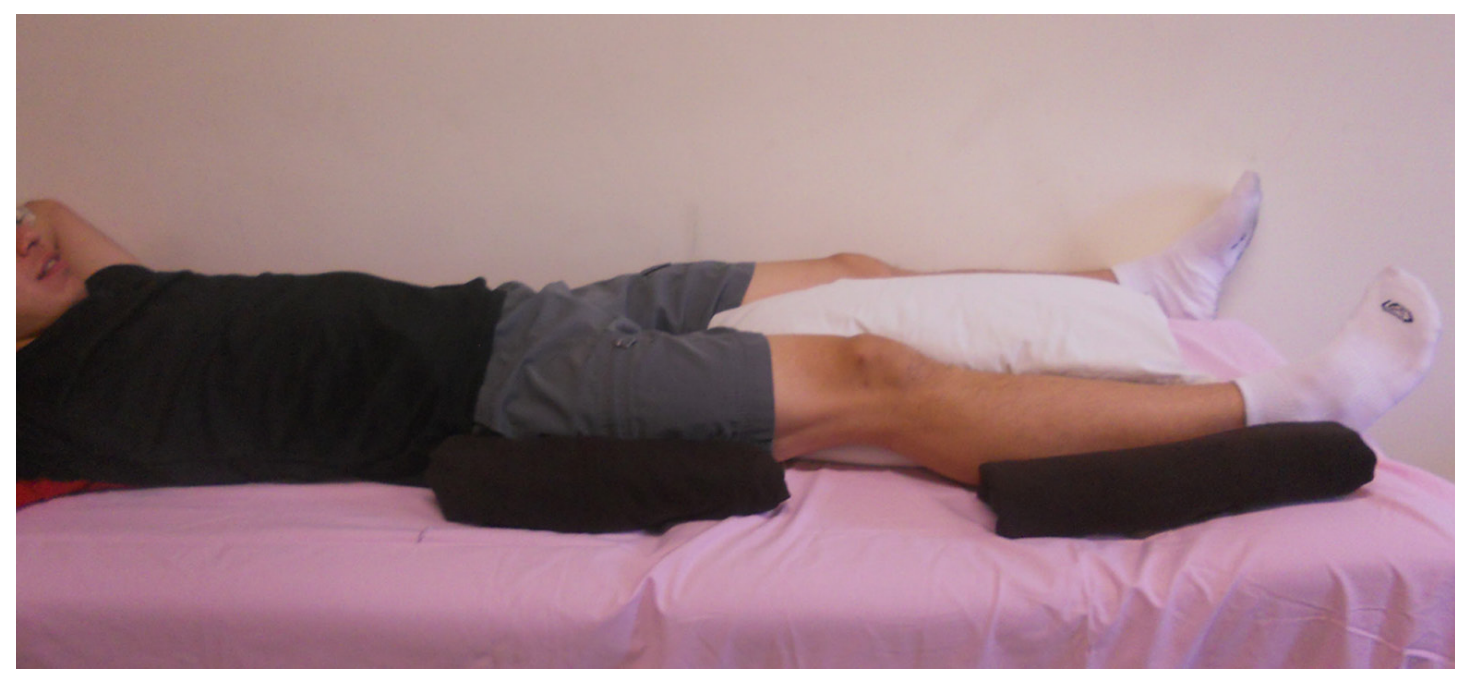

Şekil 1. Sırtüstü yatmada düzgün pozisyonlama.
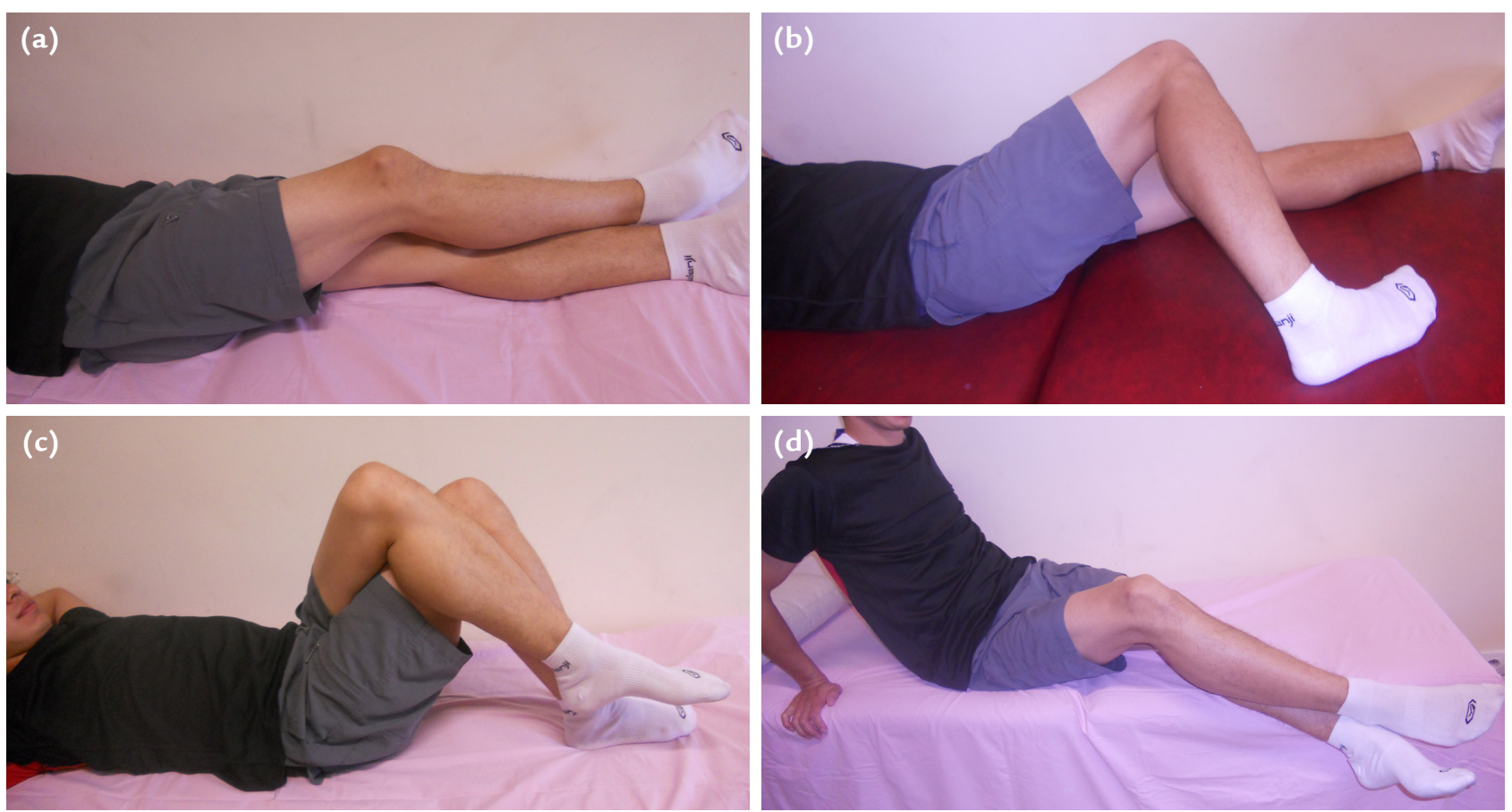

Şekil 2. Yatakta kaçınılması gereken hareketler: Nötrali geçen adduksiyon (a). Fleksiyon ve iç rotasyon (b). Bacak bacak üstüne atma (c). Sağlam bacakla ameliyatlı bacağı taşıma (d). 

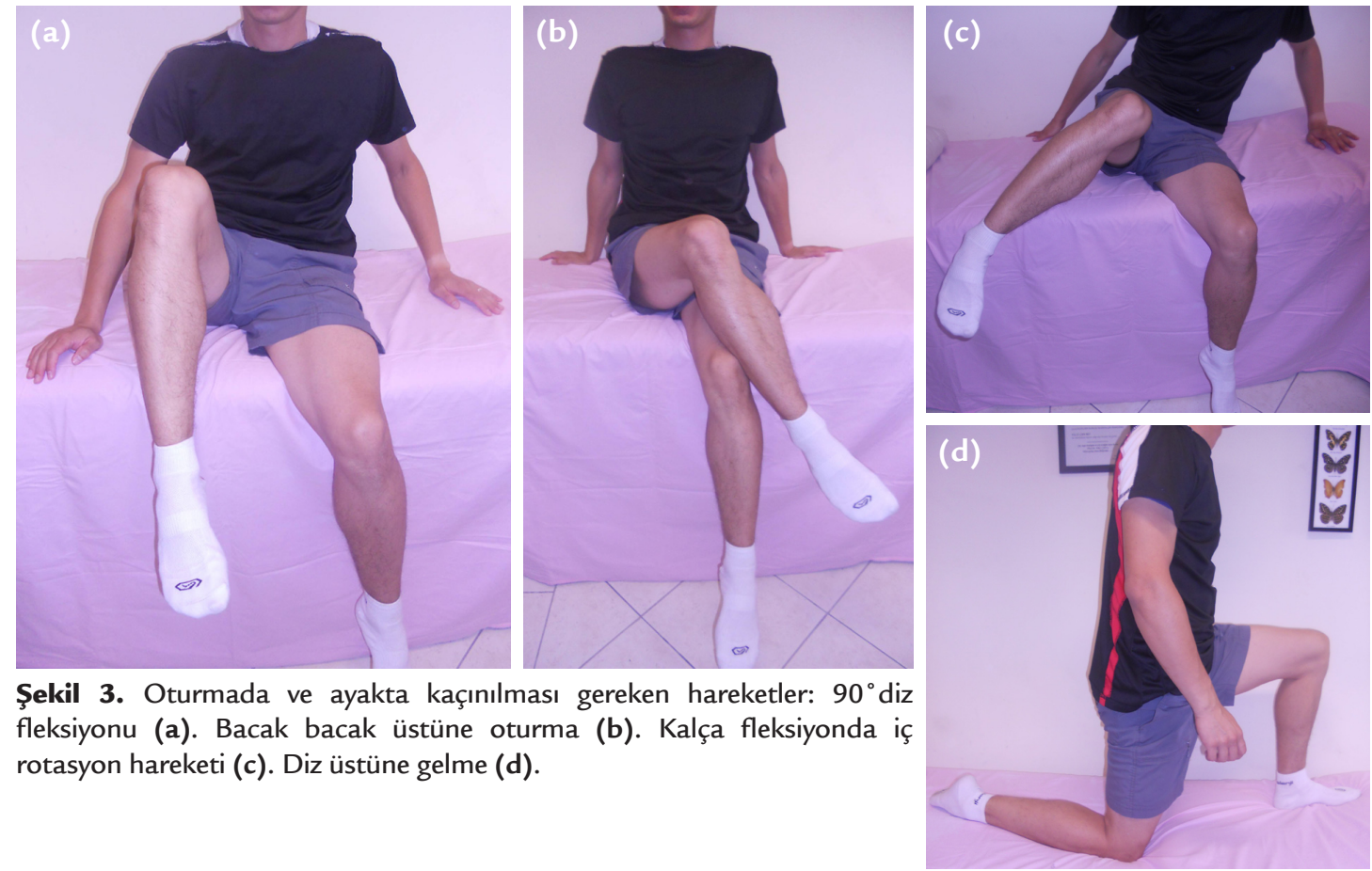

Şekil 3. Oturmada ve ayakta kaçınılması gereken hareketler: $90^{\circ} \mathrm{diz}$ fleksiyonu (a). Bacak bacak üstüne oturma (b). Kalça fleksiyonda iç rotasyon hareketi (c). Diz üstüne gelme (d).
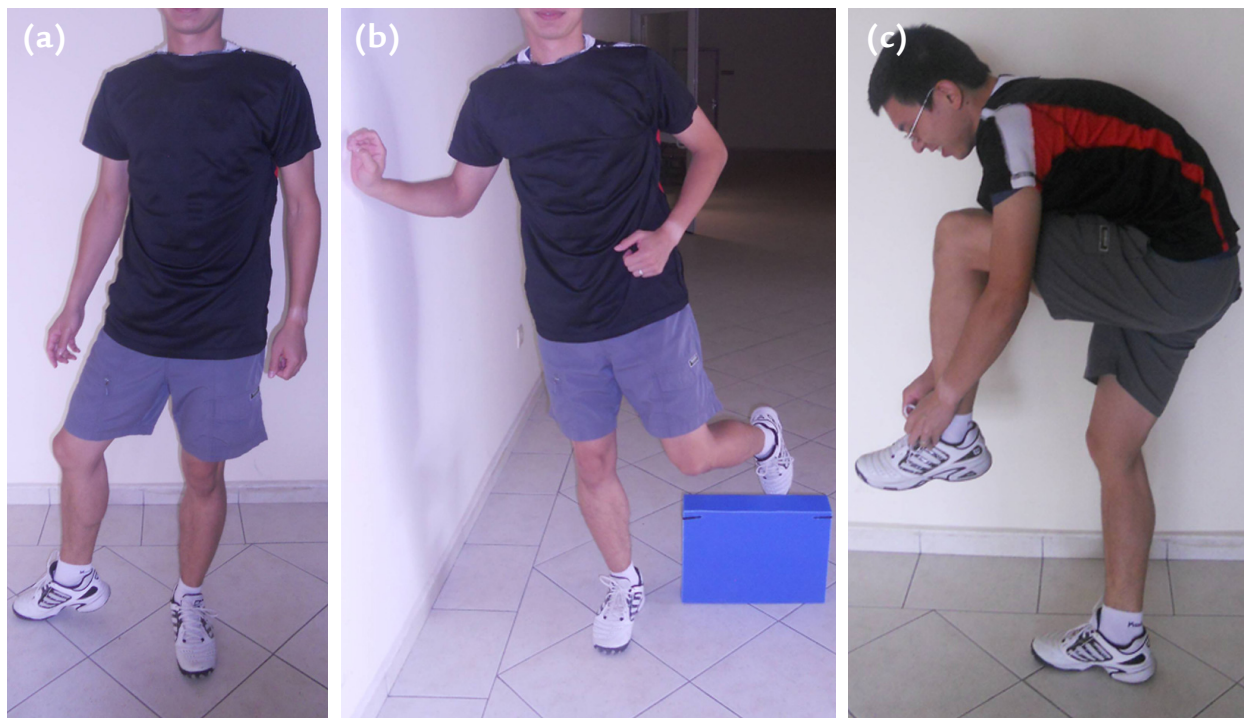

Şekil 4. Ayakta kaçınılması gereken hareketler: Ameliyatlı bacak üzerine dönme (a). Engel atlarken kalça iç rotasyonu (b). Aşırı kalça fleksiyonu ile ayakkabı giyme (c).

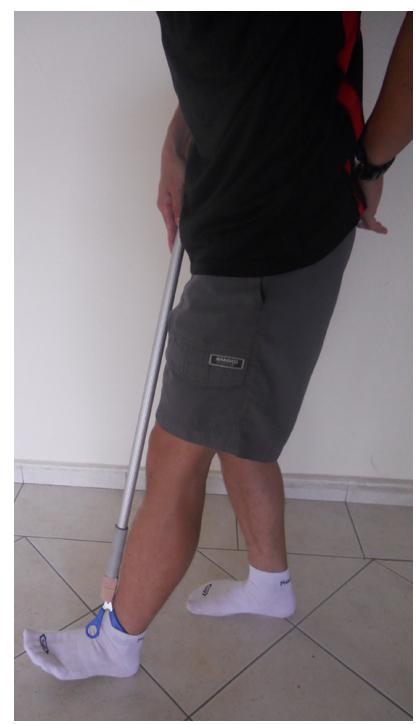

Şekil 5. Çorap çekeceği kullanma. 


\section{KAYNAKLAR}

1. Pratt E, Gray PA, Amiran MS. Total Hip Artroplasty. In: Maxey L, Magnusson J, editors. Rehabilitation for the Postsurgical Orthopedic Patient. 2nd ed. Louise Missouri: Mosby Elsevier; 2007. p.293-308.

2. Galea MP, Levinger P, Lythgo N, Cimoli C, Weller R, Tully E, McMeeken J, Westh R. A targeted home- and center-based exercise program for people after total hip replacement: a randomized clinical trial. Arch Phys Med Rehabil 2008;89(8):1442-7. CrossRef

3. Towheed TE, Hochberg MC. Health-related quality of life after total hip replacement. Semin Arthritis Rheum 1996;26(1):483-91.

4. Youm T, Maurer SG, Stuchin SA. Postoperative management after total hip and knee arthroplasty. J Arthroplasty 2005;20(3):322-4.

5. Gogia PP, Christensen CM, Schmidt C. Total hip replacement in patients with osteoarthritis of the hip: improvements in pain and functional status. Orthopaedics 1994;17(2):145-50.

6. Jensen C, Aagaard P, Overgaard S. Recovery in mechanical muscle strength following resurfacing vs standard total hip arthroplasty - a randomised clinical trial. Osteoarthritis Cartilage 2011;19(9):1108-16. CrossRef

7. Shih $\mathrm{CH}$, Du YK, Lin YH, Wu CC. Muscular recovery around the hip joint after total hip arthroplasty. Clin Orthop Relat Res 1994;(302):115-20.

8. Trudelle-Jackson E, Smith SS. Effects of a late-phase exercise program after total hip arthroplasty: a randomized controlled trial. Arch Phys Med Rehabil 2004;85(7):1056-62.

9. Horstmann $T$, Listringhaus $R$, Haase GB, Grau $S$, Mündermann A, Changes in gait patterns and muscle activity following total hip arthroplasty: A six-month follow-up. Clin Biomech (Bristol, Avon) 2013;28(7):762-9. CrossRef

10. Vaz MD, Kramer JF, Rorabeck $\mathrm{CH}$, Bourne RB. Isometric hip abductor strength following total hip replacement and its relationship to functional assessments. J Orthop Sports Phys Ther 1993;18(4):526-31.

11. Frost KL, Bertocci GE, Wassinger CA, Munin MC, Burdett RG, Fitzgerald SG. Isometric performance following total hip arthroplasty and rehabilitation. J Rehabil Res Dev 2006;43(4):435-44

12. Bhave A, Marker DR, Seyler TM, Ulrich SD, Plate JF, Mont MA. Functional problems and treatment solutions after total hip arthroplasty. J Arthroplasty 2007;22(6 Suppl 2):116-24.

13. Sicard-Rosenbaum L, Light KE, Behrman AL. Gait, lower extremity strength, and self-assessed mobility after hip arthroplasty. J Gerontol A Biol Sci Med Sci 2002;57(1):47-51.

14. White SC, Lifeso RM. Altering asymmetric limb loading after hip arthroplasty using real-time dynamic feedback when walking. Arch Phys Med Rehabil 2005;86(10):1958-63.

15. Miki H, Sugano N, Hagio K, Nishii T, Kawakami H, Kakimoto A, Nakamura N, Yoshikawa $\mathrm{H}$. Recovery of walking speed and symmetrical movement of the pelvis and lower extremity joints after unilateral THA. J Biomech 2004;37(4):443-55.

16. Talis VL, Grishin AA, Solopova IA, Oskanyan TL, Belenky VE, Ivanenko YP. Asymmetric leg loading during sit-to-stand, walking and quiet standing in patients after unilateral total hip replacement surgery. Clin Biomech (Bristol, Avon) 2008;23(4):424-33. CrossRef

17. Vogt L, Brettmann K, Pfeifer K, Banzer W. Walking patterns of hip arthroplasty patients: some observations on the medio-lateral excursions of the trunk. Disabil Rehabil 2003;25(7):309-17.
18. Nantel J, Termoz N, Vendittoli P-A, Lavigne M, Prince F. Gait patterns after total hip arthroplasty and surface replacement arthroplasty. Arch Phys Med Rehabil 2009;90(3):463-9. CrossRef

19. Beaulieu ML, Lamontagne M, Beaulé PE. Lower limb biomechanics during gait do not return to normal following total hip arthroplasty. Gait Posture 2010;32(2):269-73. CrossRef

20. Bhave A, Mont M, Tennis S, Nickey M, Starr R, Etienne G. Functional problems and treatment solutions after total hip and knee joint arthroplasty. J Bone Joint Surg Am 2005;87 Suppl 2:9-11.

21. Ewen AM, Stewart S, Clair Gibson AS, Kashyap SN, Caplan $\mathrm{N}$. Post-operative gait analysis in total hip replacement patients-A review of current literature and meta-analysis. Gait Posture 2012;36(1):1-6. CrossRef

22. Cameron H, Brotzman B. The Arthritic Lower Extremity. In: Brotzman BS, Wilk KE, editors. Clinical Orthopaedic Rehabilitation. 2nd ed. Philadelphia: Mosby Inc.; 2003. p.445-58.

23. Gaspis JJ, Grabois M, Borrell RM, Menken SA, Kelly M. Limb load monitor: evaluation of a sensory feedback device for controlled weight bearing. Arch Phys Med Rehabil 1982;63(1):38-41.

24. Majewski M, Bischoff-Ferrari HA, Gruneberg C, Dick W, Allum $\mathrm{JH}$. Improvements in balance after total hip replacement. J Bone Joint Surg Br 2005;87(10):1337-43.

25. Fortin PR, Clarke AE, Joseph L, Liang MH, Tanzer M, Ferland D, Phillips C, Partridge AJ, Bélisle P, Fossel AH, Mahomed $N$, Sledge CB, Katz JN. Outcomes of total hip and knee replacement: preoperative functional status predicts outcomes at six months after surgery. Arthritis Rheum 1999;42(8):1722-8.

26. Sashika H, Matsuba $Y$, Watanabe $Y$. Home program of physical therapy: effect on disabilities of patients with total hip arthroplasty. Arch Phys Med Rehabil 1996;77(3):273-7.

27. Brander VA, Malhotra S, Jet J, Heinemann AW, Stulberg SD. Outcome of hip and knee arthroplasty in persons aged 80 years and older. Clin Orthop Relat Res 1997;(345):67-78.

28. Bennett D, Humphreys L, O'Brien S, Kelly C,. Orr JF, Beverland DE. Gait kinematics of age-stratified hip replacement patients-A large scale, long-term follow-up study. Gait Posture 2008;28(2):194-200. CrossRef

29. Can F. Total Kalça Artroplastilerinde Rehabilitasyon. Artroplasti Artroskopik Cerrahi 1994;5(9):30-1.

30. Iyengar KP, Nadkarni JB, Ivanovic N, Mahale A. Targeted early rehabilitation at home after total hip and knee joint replacement: Does it work? Disabil Rehabil 2007;29(6):495-502.

31. Gilbey HJ, Ackland TR, Wang AW, Morton AR, Trouchet $\mathrm{T}$, Trapper J. Exercise improves early functional recovery after total hip arthroplasty. Clin Orthop Relat Res 2003;(408):193-200.

32. Genêt F, Gouin F, Coudeyre E, Revel M, Rannou F. Professional practices and recommendations. The benefits of ambulatory physiotherapy for patients able to leave the surgery department directly for home just after total hip replacement. Development of French guidelines for clinical practice. Ann Readapt Med Phys 2007;50(9):776-82.

33. Gill SD, McBurney $\mathrm{H}$. Does exercise reduce pain and improve physical function before hip or knee replacement surgery? A Systematic review and meta-analysis of randomized controlled trials. Arch Phys Med Rehabil 2013;94(1):164-76. CrossRef 
34. Smith TO, McCabe C, Lister S, Christie SP, Cross J. Rehabilitation implications during the development of the Norwich Enhanced Recovery Programme (NERP) for patients following total knee and total hip arthroplasty. Orthop Traumatol Surg Res 2012;98(5):499-505. CrossRef

35. Ganz SB, Wilson PD Jr, Cioppa-Mosca J, Peterson MG. The day of discharge after total hip arthroplasty and the achievement of rehabilitation functional milestones 11-Year Trends. J Arthroplasty 2003;18(4):453-7.

36. Coudeyre E, Jardin C, Givron P, Ribinik P, Revel M, Rannou F. Could preoperative rehabilitation modify postoperative outcomes after total hip and knee arthroplasty? Elaboration of French clinical practice guidelines. Ann Readapt Med Phys 2007;50(3):189-97.

37. McGregor AH, Rylands $\mathrm{H}$, Owen A, Doré CJ, Hughes, SP. Does preoperative hip rehabilitation advice improve recovery and patient satisfaction? J Arthroplasty 2004;19(4):464-8.

38. Oosting E, Jans MP, Dronkers JJ, Naber RH, DronkersLandman CM, Appelman-de Vries SM, van Meeteren NL. Preoperative home-based physical therapy versus usual care to improve functional health of frail older adults scheduled for elective total hip arthroplasty: a pilot randomized controlled trial. Arch Phys Med Rehabil 2012;93(4):610-6. CrossRef

39. LeVeau B. Hip. In: Richardson JK, Iglarsh ZA, editors. Clinical Orthopaedic Physical Therapy. Philadelphia: W.B. Saunders Company; 1994. p.386-391.

40. Dauty M, Genty M, Ribinik P. Physical training in rehabilitation programs before and after total hip and knee arthroplasty. Ann Readapt Med Phys 2007;50(6):462-8, 455-61.

41. Heiberg KE, Ekeland A, Bruun-Olsen V, Mengshoel AM. Recovery and prediction of physical functioning outcomes during the first year after total hip arthroplasty. Arch Phys Med Rehabil 2013;94(7):1352-9. CrossRef

42. Biggs A. Physiotherapy following surgery to the lower limb. In: Downie PA, Tidswell MA (2nd edition editor). Cash's Textbook of Orthopaedics and Rheumatology for Physiotherapists. 2nd ed. London: Mosby - Year Book Europe Ltd.; 1992. p.340-47.

43. Lowrey CE, Coutts RD. Rehabilitation of the hip. In: Nickel VL, Botte MJ, editors. Orthopaedic Rehabilitation. 2nd ed. New York: Churchill Livingstone; 1992. p.779-85.

44. Ribinik P, Le Moine F, de Korvin G, Coudeyre E, Genty M, Rannou F, Yelnik A, Calmels P. Physical and Rehabilitation Medicine (PRM) care pathways: "patients after total hip arthroplasty". Ann Phys Rehabil Med 2012;55(8):540-45. CrossRef

45. Vincent HK, Alfano AP, Lee L, Vincent KR. Sex and age effects on outcomes of total hip arthroplasty after inpatient rehabilitation. Arch Phys Med Rehabil 2006;87(4):461-7.

46. Holstege MS, Lindeboom R, Lucas C. Preoperative quadriceps strength as a predictor for short-term functional outcome after total hip replacement. Arch Phys Med Rehabil 2011;92(2):236-41. CrossRef

47. Suetta C, Magnusson SP, Rosted A, Aagaard P, Jakobsen AK, Larsen LH, Duus B, Kjaer M. Resistance training in the early postoperative phase reduces hospitalization and leads to muscle hypertrophy in elderly hip surgery patients-a controlled, randomized study. J Am Geriatr Soc 2004;52(12):2016-22

48. Husby VS, Helgerud J, Bjørgen S, Husby OS, Benum P, Hoff J. Early maximal strength training is an efficient treatment for patients operated with total hip arthroplasty. Arch Phys Med Rehabil 2009;90(10):1658-67. CrossRef
49. Ries MD, Quinn M. Postoperative rehabilitation in primary total hip arthroplasty. Operative Techniques in Orthopaedics 1995;5(4):356-60.

50. Jan MH, Hung JY, Lin JC, Wang SF, Liu TK, Tang PF. Effects of a home program on strength, walking speed, and function after total hip replacement. Arch Phys Med Rehabil 2004;85(12):1943-51.

51. Gremeaux V, Renault J, Pardon L, Deley G, Lepers R, Casillas JM. Low-frequency electric muscle stimulation combined with physical therapy after total hip arthroplasty for hip osteoarthritis in elderly patients: a randomized controlled trial. Arch Phys Med Rehabil 2008;89(12):2265-73. CrossRef

52. Giaquinto S, Ciotola E, Dall'armi V, Margutti F. Hydrotherapy after total hip arthroplasty: a follow-up study. Arch Gerontol Geriatr 2010;50(1):92-5. doi: 10.1016/j. archger.2009.02.005

53. Giaquinto S, Ciotola E, Margotti F, Valentini F. Gait during hydrokinesitherapy following total hip arthroplasty. Disabil Rehabil 2007;29(9):743-49.

54. Giaquinto S, Margutti F, Romano F. A special pool project for rehabilitation of hip and knee arthroprosthesis. Disabil Rehabil 2004;26(19):1158-62.

55. Liebs TR, Herzberg W, Ruther W, Haasters J, Russlies M, Hassenpflug J; Multicenter Arthroplasty Aftercare Project. Multicenter randomized controlled trial comparing early versus late aquatic therapy after total hip or knee arthroplasty. Arch Phys Med Rehabil 2012;93(2):192-9. CrossRef

56. Rahmann AE, Brauer SG, Nitz JC. A specific inpatient aquatic physiotherapy program improves strength after total hip or knee replacement surgery: a randomized controlled trial. Arch Phys Med Rehabil 2009;90(5):745-55. CrossRef

57. Trudelle-Jackson E, Emerson R, Smith S. Outcomes of total hip arthroplasty: a study of patients one year post-surgery. J Orthop Sports Phys Ther 2002;32(6):260-7.

58. Monaghan B, Grant T, Hing W, Cusack T. Functional exercise after total hip replacement (FEATHER) a randomised control trial. BMC Musculoskelet Disord 2012;13:237. CrossRef

59. Cacko MA, Keener JD. Total Hip Artroplasty. In: Placzek JD, Boyce DA, editors. Orthopaedic Physical Therapy Secret. 2 nd ed. St Louis, Missouri: Mosby Elsevier; 2006. p.539-43.

60. Dorr LD, Wan Z. Causes of and treatment protocol for instability of total hip replacement. Clin Orthop Relat Res 1998;(355):144-51.

61. Johnston JJ, Noble PC, Hurwitz DE, Andriacchi TP. Biomechanics of the hip. In: Callaghan JJ, Rosenberg AG, Rubash HE, editors. The adult hip. 2nd ed. Philadelphia: Lippincott, Williams \& Wilkins; 2007. p.81-90.

62. Karanjia PN, Ferguson JH. Passive joint position sense after total hip replacement surgery. Ann Neurol 1983;13(6):654-7.

63. Sliwinski MM, Sisto SA, Batavia M, Chen B, Forrest GF. Dynamic stability during walking following unilateral total hip arthroplasty. Gait Posture 2004;19(2):141-7.

64. McCrory JL, White SC, Lifeso RM. Vertical ground reaction forces: objective measures of gait following hip arthroplasty. Gait Posture 2001;14(2):104-9.

65. Peron M, Malouin F, Moffet H. Assessing advanced locomotor recovery after total hip arthroplasty with the timed stair test. Clin Rehabil 2003;17(7):780-6.

66. Kiss RM, Illyés Á. Comparison of gait parameters in patients following total hip arthroplasty with a direct-lateral or anterolateral surgical approach. Hum Mov Sci 2012;31(5):130216. CrossRef 
67. Smith TO, Mann CJ, Clark A, Donell ST. Bed exercises following total hip replacement: 1 year follow-up of a singleblinded randomised controlled trial. Hip Int 2009;19(3):26873. Physiotherapy 2008;94:286-91.

68. van den Akker-Scheek I, Stevens M, Bulstra SK, GroothoffJW, van Horn JR, Zijlstra W. Recovery of gait after short-stay total hip arthroplasty. Arch Phys Med Rehabil 2007;88(3):361-7.

69. Merle J, Rougier P, Belaid D, Cantalloube S, Lamotte D. Is early weight bearing resumption beneficial after total hip replacement? Orthop Traumatol Surg Res 2009;95(2):12733. CrossRef

70. Dean E, Ross J. Relationship among cane fitting, function, and falls. Phys Ther 1993;73(8):494-504.

71. Brand RA, Crowninshield RD. The effect of cane use on hip contact force. Clin Orthop Relat Res 1980;(147):181-4.
72. Ajemian S, Thon D, Clare P, Kaul L, Zernicke RF, Loitz-Ramage B. Cane-assisted gait biomechanics and electromyography after total hip arthroplasty. Arch Phys Med Rehabil 2004;85(12):1966-71.

73. Krebs DE, Robbins CE, Lavine L, Mann RW. Hip biomechanics during gait. J Orthop Sports Phys Ther 1998;28(1):51-9.

74. Krebs D, Elbaum L, Riley PO, Hodge WA, Mann RW. Exercise and gait effects on in vivo hip contact pressures. Phys Ther 1991;71(4):301-9.

75. Pataky Z, De León Rodriguez D, Golay A, Assal M, Assal JP, Hauert CA. Biofeedback training for partial weight bearing in patients after total hip arthroplasty. Arch Phys Med Rehabil 2009;90(8):1435-8. CrossRef 